\title{
Properties and Fate of Oligodendrocyte Progenitor Cells in the Corpus Callosum, Motor Cortex, and Piriform Cortex of the Mouse
}

\author{
Laura E. Clarke, ${ }^{1 \star}$ Kaylene M. Young, ${ }^{1,2,3 *}$ Nicola B. Hamilton, ${ }^{1}$ Huiliang Li, ${ }^{2}$ William D. Richardson, ${ }^{2}$ and \\ David Attwell ${ }^{1}$ \\ ${ }^{1}$ Department of Neuroscience, Physiology, and Pharmacology and ${ }^{2}$ Wolfson Institute for Biomedical Research and Department of Cell and Developmental \\ Biology, University College London, London, WC1E 6BT, United Kingdom, ${ }^{3}$ The Menzies Research Institute Tasmania, University of Tasmania, Tasmania, \\ Australia, 7000
}

Oligodendrocyte progenitor cells (OPCs) in the postnatal mouse corpus callosum (CC) and motor cortex (Ctx) reportedly generate only oligodendrocytes (OLs), whereas those in the piriform cortex may also generate neurons. OPCs have also been subdivided based on their expression of voltage-gated ion channels, ability to respond to neuronal activity, and proliferative state. To determine whether OPCs in the piriform cortex have inherently different physiological properties from those in the CC and Ctx, we studied acute brain slices from postnatal transgenic mice in which GFP expression identifies OL lineage cells. We whole-cell patch clamped GFP-expressing $\left(\mathrm{GFP}^{+}\right)$cells within the $\mathrm{CC}, \mathrm{Ctx}$, and anterior piriform cortex (aPC) and used prelabeling with 5-ethynyl-2' -deoxyuridine (EdU) to assess cell proliferation. After recording, slices were immunolabeled and OPCs were defined by strong expression of NG2. NG2 ${ }^{+}$OPCs in the white and gray matter proliferated and coexpressed PDGFR $\alpha$ and voltage-gated $\mathrm{Na}^{+}$channels $\left(\mathrm{I}_{\mathrm{Na}}\right)$. Approximately $70 \%$ of 0 PCs were capable of generating regenerative depolarizations. In addition to OLIG2 ${ }^{+} \mathrm{NG}_{2}{ }^{+} \mathrm{I}_{\mathrm{Na}}{ }^{+}$OPCs and OLIG2 ${ }^{+} \mathrm{NG} 2{ }^{\text {neg }} \mathrm{I}_{\mathrm{Na}}{ }^{\text {neg }}$ OLs, we identified cells with low levels of NG2 limited to the soma or the base of some processes. These cells had a significantly reduced $\mathrm{I}_{\mathrm{Na}}$ and a reduced ability to incorporate EdU when compared with OPCs and probably correspond to early differentiating OLs. By combining EdU labeling and lineage tracing using $P d g f r \boldsymbol{\alpha}-C r e E R^{T 2}: R 26 R-Y F P$ transgenic mice, we double labeled OPCs and traced their fate in the postnatal brain. These OPCs generated OLs but did not generate neurons in the aPC or elsewhere at any time that we examined.

\section{Introduction}

Oligodendrocytes (OLs) are produced by proliferating precursors, oligodendrocyte progenitor cells (OPCs), that express PDGFR $\alpha$ and NG2 proteoglycan. OPCs receive depolarizing synaptic input from unmyelinated glutamatergic and GABAergic neurons (Bergles et al., 2000; Lin and Bergles, 2004; Kukley et al., 2007, 2008, 2010; Ziskin et al., 2007), and some OPCs can fire regenerative action potential-like depolarizations (Chittajallu et al., 2004; Káradóttir et al., 2008; Ge et al., 2009). The function of this signaling is uncertain, but in vitro neurotransmitters alter OPC migration and differentiation (Yuan et al., 1998; Gudz et al., 2006; Tong et al., 2009). Furthermore, axonal stimulation pro-

Received Feb. 27, 2012; revised April 19, 2012; accepted April 25, 2012.

Author contributions: L.E.C., K.M.Y., N.B.H., W.D.R., and D.A. designed research; L.E.C., K.M.Y., and N.B.H. performed research; K.M.Y. and H.L. contributed unpublished reagents/analytic tools; L.E.C., K.M.Y., and D.A. analyzed data; L.E.C., K.M.Y., W.D.R., and D.A. wrote the paper.

*L.E.C. and K.M.Y. contributed equally to this work.

L.E.C. was supported by a 4-year PhD studentship from the Wellcome Trust. K.M.Y. was supported by a fellowship and grant from the Alzheimer's Society, UK and the Bupa Foundation. This work was funded by research grants from the Wellcome Trust, the Medical Research Council, National Health and Medical Research Council Grant 1030939, the National Institutes of Health, and the European Union (Leukotreat). We thank Ulla Dennehy for technical help.

Correspondence should be addressed to David Attwell, Department of Neuroscience, Physiology, and Pharmacology, University College London, Gower Street, London, WC1E 6BT. E-mail: d.attwell@ucl.ac.uk.

DOI:10.1523/JNEUROSCI.0928-12.2012

Copyright $\odot 2012$ the authors $\quad 0270-6474 / 12 / 328173-13 \$ 15.00 / 0$ motes OPC proliferation and OL differentiation (Li et al., 2010), whereas blocking action potentials retards myelination (Barres and Raff, 1993; Demerens et al., 1996). More recently, vesicular release of glutamate was demonstrated to promote myelin protein translation at axon-OL contacts (Wake et al., 2011), supporting the idea that synaptic communication modulates myelination.

Whether all OPCs are the same is controversial. On the one hand, it has been suggested that all OPCs express voltage-gated sodium $\left(\mathrm{I}_{\mathrm{Na}}\right)$ and potassium channels, which are downregulated when OPCs differentiate to form OLs (De Biase et al., 2010; Kukley et al., 2010). On the other hand, NG2-expressing $\left(\mathrm{NG}^{+}{ }^{+}\right)$ OPCs in the rat cerebellar white matter fall into two classes: one that receives synaptic input, expresses $\mathrm{I}_{\mathrm{Na}}$, and can generate action potentials and another that lacks these attributes (Káradóttir et al., 2008). Voltage-gated ion channel expression and spiking behavior also reportedly differ between white and gray matter OPCs (Chittajallu et al., 2004). Furthermore, perinatal OPCs have been shown to produce OLs and astrocytes in vivo, whereas postnatal OPCs generate only OLs, except in the piriform cortex in which they have been reported to also produce some neurons (Dayer et al., 2005; Tamura et al., 2007; Rivers et al., 2008; Guo et al., 2010; Zhu et al., 2011).

Despite reports of neurogenesis in the piriform cortex (Bernier et al., 2002; Pekcec et al., 2006; Shapiro et al., 2007; Arisi 
et al., 2012), the source of the new neurons is contentious, with the main candidates being neural stem cells and OPCs. In many brain regions, OPCs express doublecortin (DCX) (Tamura et al., 2007; Guo et al., 2010; Ehninger et al., 2011), a marker of migratory neuroblasts, but those in the piriform cortex also express the neuroblast marker polysialylated neural cell adhesion molecule (PSA-NCAM) and the neural precursor markers Sox2 and Pax6 (Seki and Arai, 1999; Hayashi et al., 2001; Nacher et al., 2002; Pekcec et al., 2006; Shapiro et al., 2007; Bullmann et al., 2010; Guo et al., 2010), suggesting that they might be a functionally distinct cell population.

We report that OPCs in the mouse corpus callosum (CC), motor cortex (Ctx), and anterior piriform cortex (aPC) have similar membrane properties: they express $\mathrm{I}_{\mathrm{Na}}$ but do not generate bona fide action potentials. By combining 5-ethynyl-2'-deoxyuridine (EdU) administration with transgenic lineage tracing, we demonstrate that OPCs within the postnatal forebrain proliferate and generate OLs but do not generate neurons at any time that we examined after postnatal day 25 (P25).

\section{Materials and Methods}

Transgenic mice. Pdgfr $\alpha-H 2 B G F P$ knock-in mice (Hamilton et al., 2003), referred to as $P d g$ fr $\alpha-G F P$ mice, were purchased from The Jackson Lab-

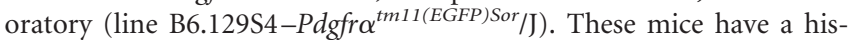
tone-GFP fusion gene knocked into the $P d g f r \alpha$ locus, resulting in nuclear labeling of PDGFR $\alpha$-expressing cells, including OPCs. Pdgfr $\alpha-G F P$ mice were genotyped by PCR using the following primers: Ra-lox, 5'-ACGA AGTTATTAGGTCCCTCGAC-3'; AR4, 5'-CCCTTGTGGTCATGCCA AAC-3'; and AR5, 5' -GCTTTTGCCTCCATTACACTGG-3' , which amplified a 451 bp wild-type and/or a 242 bp mutant DNA fragment.

Homozygous $P d g f r \alpha-C r e E R^{T 2}$ bacterial artificial chromosome (BAC) transgenic mice (Rivers et al., 2008) were crossed with Cre-sensitive reporter mice [homozygous R26R-YFP transgenic mice (Srinivas et al., 2001) or heterozygous Tau-lox-STOP-lox-mGFP-IRES-NLS-LacZ-pA (Tau-mGFP) mice (Hippenmeyer et al., 2005)] to generate doubleheterozygous offspring for analysis. Genotyping for Cre and R26R-YFP was performed by PCR amplification of genomic DNA as described previously (Rivers et al., 2008). PCR genotyping for $m G F P$ (encoding a membrane-tethered version of GFP) was with GFP-specific primers: $5^{\prime}$ CCCTGAAGTTCATCTGCACCAC-3' and 5'-TTCTCGTTGGGGTCTT TGCTC-3'.

Tamoxifen administration. Tamoxifen (Sigma) was dissolved to 40 $\mathrm{mg} / \mathrm{ml}$ in corn oil by sonicating at $21^{\circ} \mathrm{C}$ for $\geq 35 \mathrm{~min}$. It was administered to young adult (P45) Pdgfr $\alpha-C r e E R^{T 2}: R 26 R-Y F P$ or $P d g f r \alpha-C r e E R^{T 2}$ : Tau-mGFP double-heterozygous mice, of either sex, by oral gavage on 4 consecutive days (each dose was $300 \mathrm{mg} / \mathrm{kg}$ tamoxifen body weight).

Electrophysiology. Coronal brain slices ( $225 \mu \mathrm{m}$ thick) were prepared from P9 (P7-P10) and P33 (P32-P34) mice, of either sex, that were prelabeled with EdU as described below. Slices were prepared in a solution containing $1 \mathrm{~mm} \mathrm{Na-kynurenate} \mathrm{(Sigma-Aldrich)} \mathrm{to} \mathrm{block} \mathrm{gluta-}$ mate receptors (this was omitted from solutions for experiments) and superfused at $33 \pm 1^{\circ} \mathrm{C}$ with bicarbonate-buffered solution, as described previously (Tripathi et al., 2011). Within a slice, a single cell expressing GFP under $P d g f r \alpha$ transcriptional control (see above) from the CC, Ctx, or aPC was whole-cell voltage clamped to determine whether it expressed or lacked $\mathrm{I}_{\mathrm{Na}}$ and filled with Alexa Fluor-568 dye. Whole-cell recordings were made from $\mathrm{GFP}^{+}$cells (OPCs had brighter GFP fluorescence than OLs; see Results). After recording, the patch electrode was removed from the cell, leaving the soma intact. The slice was then immersion fixed in $4 \%(\mathrm{w} / \mathrm{v})$ paraformaldehyde (PFA) in PBS at $21^{\circ} \mathrm{C}$ for a minimum of $1 \mathrm{~h}$ (maximum of $6 \mathrm{~h}$ ). These cells were also processed to detect GFP and NG2, with or without EdU, as described below. Some slices were briefly fixed for $20 \mathrm{~min}$ at $21^{\circ} \mathrm{C}$ to allow immunolabeling with anti-PDGFR $\alpha$ (this antibody is fixation sensitive).

Patch electrodes had a resistance between 5 and $8 \mathrm{M} \Omega$ when filled with a solution containing the following (in $\mathrm{mM}$ ): 130 potassium gluconate, 4 $\mathrm{NaCl}, 0.5 \mathrm{CaCl}_{2}$, 10 HEPES, 10 BAPTA, $4 \mathrm{MgATP}$, and $0.5 \mathrm{Na}_{2} \mathrm{GTP}$, with
Alexa Fluor-568 dye (Invitrogen), pH set to 7.3 with KOH. Voltage-gated sodium and potassium currents were elicited with a series of voltage steps (from -110 to $10 \mathrm{mV}$, in $20 \mathrm{mV}$ increments) from a holding potential of $-70 \mathrm{mV}$. Tetrodotoxin (TTX) at $1 \mu \mathrm{M}$ (Tocris Bioscience) was applied in the superfusion solution to block sodium current. The peak net inward current (reflecting the difference between the inward $\mathrm{I}_{\mathrm{Na}}$ and the other voltage-dependent outward currents) was quantified after subtracting the capacity current and an assumed ohmic leak current, scaled from the response to hyperpolarizing pulses. Voltage responses to current injection were recorded from the resting potential of the cell (applying $20 \mathrm{pA}$ steps for $200 \mathrm{~ms}$ ). An Axopatch 200B amplifier (Molecular Devices) was used for voltage and current clamp, and electrode junction potentials were compensated. Data were sampled at $50 \mathrm{kHz}$ and filtered at $10 \mathrm{kHz}$ using pClamp 9.2, and offline analysis was performed using Clampfit 9.2 (Molecular Devices).

Tissue preparation and immunolabeling. Mice were perfusion fixed with 4\% PFA in PBS. Brains were removed and sliced into $2 \mathrm{~mm}$ coronal slices using a rodent brain matrix (Agar Scientific). Brain slices were immersion fixed in $4 \%$ PFA in PBS at $4^{\circ} \mathrm{C}$ overnight (except for PDGFR $\alpha$ immunolabeling in which tissue was immersion fixed for $45 \mathrm{~min}$ at $21^{\circ} \mathrm{C}$ ) and cryoprotected in $20 \%(\mathrm{w} / \mathrm{v})$ sucrose in PBS at $4^{\circ} \mathrm{C}$ for $6 \mathrm{~h}$, before embedding in Optimal Cutting Temperature medium (Tissue-Tek). Frozen tissue was stored at $-80^{\circ} \mathrm{C}$. Cryosections (30 $\mu \mathrm{m}$ thick) were collected and immunohistochemistry was performed on floating sections as described previously (Young et al., 2007).

The following primary antibodies were used: rabbit anti-GFP serum (1:1000; Synaptic Systems), rat anti-GFP IgG2a (1:3000; Nacalai Tesque), rat monoclonal anti-PDGFR $\alpha$ (1:400; BD Biosciences Pharmingen), rabbit anti-NG2 (1:500; Millipore), rabbit anti-OLIG2 (1: 1000; Millipore), mouse anti-neuron-specific nuclear protein (NeuN) (1:500; Millipore), mouse anti-glial fibrillary acidic protein (1:2000; Sigma), rabbit anti-somatostatin (SST) (1:100; Peninsular Laboratories), rabbit anti-neuropeptide Y (NPY) (1:1000; Insight), rabbit antiparvalbumin (1:1000; Millipore Bioscience Research Reagents), mouse anti-calbindin (1:1000; Swant), rabbit anti-calretinin (1:1000; Swant), mouse anti-PSA-NCAM IgM (1:500; Millipore Bioscience Research Reagents), mouse anti-reelin (1:2000; a gift from A. Goffinet, University of Louvain, Louvain, Belgium), rabbit anti-Iba1 (1:1000; Synaptic Systems), guinea-pig anti-DCX (1:1000; Millipore), and mouse monoclonal CC1 (1:200; against adenomatous polyposis antigen; Calbiochem). Secondary antibodies were goat anti-rat (1:500), donkey anti-rabbit (1: 1000 ), goat anti-mouse IgM or goat anti-mouse IgG (heavy and light chains) (1:1000) conjugated with Alexa Fluor-405, Alexa Fluor-488, Alexa Fluor-568, or Alexa Fluor-647 (Invitrogen), and goat anti-guinea pig Cy3 (1:500; Millipore Bioscience Research Reagents). Cell nuclei were visualized by post-staining with Hoechst 33258 (1:1000; Sigma). When immunolabeling with CC1, Tris-buffered saline (TBS) blocking solution [TBS containing $0.5 \%(\mathrm{v} / \mathrm{v})$ Triton X-100 and $10 \%$ fetal calf serum] was used in place of PBS blocking solution, and all washes were performed in TBS.

EdU labeling and detection. EdU (Invitrogen) is a thymidine analog that is incorporated into the DNA of cells as they undergo DNA replication. EdU was administered to mice either as a series of subcutaneous injections (for mice aged P10 or younger) or via the drinking water (for mice aged P20 or older). For subcutaneous injections, EdU was dissolved at $1 \mathrm{mg} / \mathrm{ml}$ in PBS, and each pup was injected with $50 \mu \mathrm{l}$ at 7:30 A.M., 10:30 A.M., 1:30 P.M., 4:30 P.M., and 7:30 P.M. for 5 consecutive days. Alternatively, EdU was dissolved in the drinking water $(0.3 \mathrm{mg} / \mathrm{ml})$ that was available ad libitum and replaced every 2-3 d. Optimization of this in vivo EdU labeling method and a more detailed comparison of in vivo BrdU and EdU labeling and detection methodologies will be detailed in a later publication (K. M. Young, K. Psachoulia, and W. D. Richardson, unpublished observations).

After fixation, tissue slices were washed once with PBS and then incubated for $20 \mathrm{~min}$ at $21^{\circ} \mathrm{C}$ in $0.8 \%(\mathrm{v} / \mathrm{v})$ Triton X-100 in PBS on an orbital shaker. The slices were again washed in PBS before EdU detection with the Click-iT EdU Alexa Fluor-647 Imaging kit (Invitrogen). Each slice was immersed in $\sim 120 \mu \mathrm{l}$ of Click-iT developing mixture and incubated for $45 \mathrm{~min}$ at $21^{\circ} \mathrm{C}$ in the dark, according to the instructions of the 

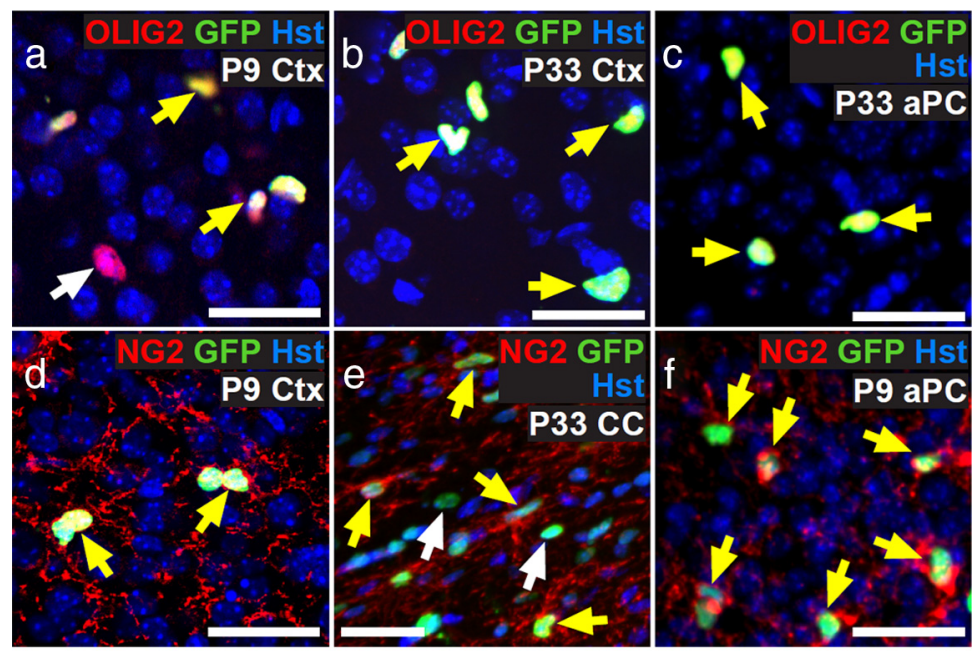

$$
\text { (1) }
$$

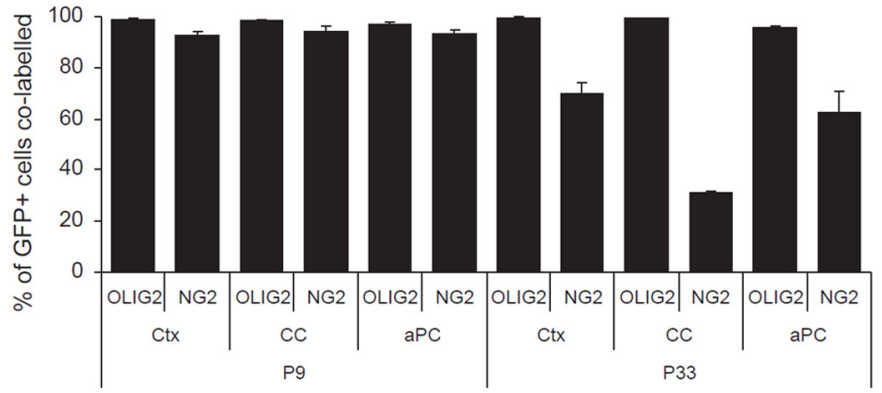

Figure 1. Pdgfr $\alpha-G F P$ mice label oligodendroglial cells in the postnatal brain. $\boldsymbol{a}-\boldsymbol{f}$, Cryosections from P9 to P33 Pdgfr $\alpha$-GFP mice were immunolabeled to detect GFP (green) with either OLIG2 (red; $\boldsymbol{a}-\boldsymbol{c}$ ) or NG2 (red; $\boldsymbol{d}-\boldsymbol{f}$ ). Doublelabeled cells are indicated by a yellow arrow and single-labeled cells by a white arrow. Sections were also stained with Hoechst 33258 (Hst; blue) to detect cell nuclei. $\boldsymbol{g}$, The proportions of GFP ${ }^{+}$cells that coexpressed each marker were quantified for the $\mathrm{Ctx}, \mathrm{CC}$, and aPC. The proportion of GFP ${ }^{+}$cells that coexpressed NG2 fell significantly from P9 to P33 (ANOVA; $p<0.01$ ). Scale bars, $20 \mu \mathrm{m}$.

manufacturer. Slices were washed once with PBS before immunolabeling for NG2 (see above).

For floating cryosections, the EdU labeling was developed immediately after immunolabeling, because some antibodies failed if the order was reversed. Floating cryosections were incubated at $21^{\circ} \mathrm{C}$ for $15 \mathrm{~min}$ in PBS with $0.5 \%(\mathrm{v} / \mathrm{v})$ Triton X-100, transferred to the EdU developing mixture, incubated in the dark at $21^{\circ} \mathrm{C}$ for $40 \mathrm{~min}$, washed three times in PBS, post-stained with Hoechst 33258 (1:1000; Sigma) to visualize cell nuclei, and mounted under coverslips in fluorescence mounting medium (Dako). Unlike BrdU detection, EdU detection does not require antigen retrieval protocols.

Microscopy and cell counts. All images were collected on an Ultraview confocal microscope (PerkinElmer Life and Analytical Sciences) as $Z$-stacks with $1 \mu \mathrm{m}$ spacing, using standard excitation and emission filters for DAPI, FITC (Alexa Fluor-488), TRITC (Alexa Fluor568), and Far Red (Alexa Fluor-647). For quantification, eight or more low-magnification $(20 \times$ objective) fields were collected within each anatomical region of interest, for each coronal brain section, including all layers of the medial Ctx, layer II of the aPC, and the CC (region between the lateral edges of the lateral ventricles). Cells were counted manually, viewing each image in Adobe Photoshop. For post-electrophysiological confocal imaging of individual cells, the Alexa Fluor-568 dye-filled cell was located within the section and scored for EdU and NG2 expression, blind to the electrophysiology data for that cell. Fluorescence intensities and cell body diameters were measured in photomicrographs using NIH Image J software (http://rsbweb.nih.gov/ij/).

Statistics. Data are presented as mean \pm SEM. $P$ values were obtained from Student's two-tailed $t$ tests or ANOVA, as specified. Cell-cycle parameters were estimated from EdU labeling as described previously (Psachoulia et al., 2009).

\section{Results}

Using Pdgfr $\alpha-G F P$ transgenic mice to identify $O L$ lineage cells in the postnatal brain

To investigate whether oligodendrogenic OPCs in the Ctx and CC of the postnatal mouse brain have electrical properties similar to the potentially neurogenic OPCs in the aPC, putative OPCs were identified by their intrinsic fluorescence in brain slices from $P d g f r \alpha-G F P$ transgenic mice (Hamilton et al., 2003). Because PDGFR $\alpha$ is expressed by OPCs but not by differentiated OLs, we would expect OPCs to be specifically labeled in these mice. Pdgfr $\alpha-G F P$ transgenic mice were used previously to identify embryonic OPCs (Hamilton et al., 2003), but the specificity of the GFP expression was not characterized postnatally. Therefore, we coimmunolabeled P9 and P33 coronal brain sections for GFP and the OL lineage marker OLIG2 (Fig. 1 $a-c$ ). In the Ctx, CC, and aPC, $>96 \%$ of all $\mathrm{GFP}^{+}$cells also expressed OLIG2 (Fig. 1g). Because NG2 immunolabeling is intense in OPCs but is lost as they differentiate into OLs, we immunolabeled additional sections for GFP and NG2 (Fig. $1 d-f$ ) to determine what proportion of the $\mathrm{GFP}^{+}$cells corresponds to OPCs. At P9, $\sim 93 \%$ of GFP antibodylabeled cells also labeled for NG2. However, by $\mathrm{P} 33$, only $\sim 70 \%$ of all $\mathrm{GFP}^{+}$cells in the Ctx, $\sim 30 \%$ of those in the CC, and $\sim 60 \%$ in the aPC also expressed NG2, suggesting that GFP persists in more mature oligodendroglial cells $\left(\mathrm{OLIG}{ }^{+} \mathrm{NG}^{\text {neg }}\right.$ ) (Fig. 1g). Therefore, in the postnatal brain of $P d g f r \alpha-G F P$ transgenic mice, GFP labeling identifies cells of the OL lineage $\left(\mathrm{OLIG}_{2}{ }^{+}\right.$) but does not distinguish between OPCs and recently differentiated OLs.

\section{Expression of voltage-gated sodium channels defines two} populations of OL lineage cells in the postnatal mouse brain To investigate the electrophysiological properties of OL lineage cells, we whole-cell patch clamped cells in the CC, Ctx, and aPC. Identified by their GFP expression, OL lineage cells in the brain of postnatal $P d g f r \alpha-G F P$ mice could be divided into two broad classes of cell. One class (termed $\mathrm{I}_{\mathrm{Na}}{ }^{+}$) produced a transient inward current after depolarization beyond $-30 \mathrm{mV}$ (Fig. $2 a-c$ ), which was blocked by TTX (Fig. $3 a$ ), indicating that it was mediated by $\mathrm{I}_{\mathrm{Na}}$. This transient inward current was followed by activation of a more sustained outward, presumably $\mathrm{K}^{+}$current $\left(\mathrm{I}_{\mathrm{K}}\right)$ (Fig. $2 a-c$ ). In contrast, the other cell type (termed $\mathrm{I}_{\mathrm{Na}}{ }^{\text {neg }}$ ) showed an essentially time-independent current-voltage $(I-V)$ relationship at negative potentials but often an outward (presumably $\mathrm{K}^{+}$) voltage-gated current on depolarization (Fig. $2 d-f$ ). When TTX was applied to this cell class, the $I-V$ relationship remained unchanged (Fig. $3 b$ ), excluding the possibility that the $\mathrm{K}^{+}$conductance was masking a voltage-gated $\mathrm{Na}^{+}$current in these cells $(n=3)$. Similar classes of cell, with and without $\mathrm{I}_{\mathrm{Na}}$, were also found in $\mathrm{GFP}^{+}$cells in the cerebellum (data not shown).

Owing to the rapid kinetics of $\mathrm{I}_{\mathrm{Na}}$, it partly overlaps with the transient capacity current, so the net inward current was quanti- 
fied after subtracting the linearly scaled capacity transient and ohmic leak current that was evoked by a hyperpolarizing pulse (Fig. 2, bottom traces). The resulting peak inward current represents a combination of $\mathrm{I}_{\mathrm{Na}}$ and $\mathrm{I}_{\mathrm{K}}$. To assess how the overlap of these currents alters the apparent magnitude of the voltage-gated $\mathrm{Na}^{+}$ current, TTX was applied to some cells to isolate $\mathrm{I}_{\mathrm{K}}$ (Fig. $3 a$ ). Subtraction of $\mathrm{I}_{\mathrm{K}}$ in these cells from the total inward current revealed a 2.5 -fold increase in the amplitude of the net inward current $(n=3)$ (Fig. 3a).

\section{$\mathrm{I}_{\mathrm{Na}}$ cells show regenerative}

action potential-like waves but do not express neuronal markers

It has been reported that some OPCs can fire action potentials in response to depolarization (Chittajallu et al., 2004; Káradóttir et al., 2008; Ge et al., 2009). In our present study, depolarizing current injection resulted in passive membrane responses in $\mathrm{I}_{\mathrm{Na}}{ }^{\text {neg }} \mathrm{GFP}^{+}$cells (Fig. 3c). $\mathrm{I}_{\mathrm{Na}}{ }^{+} \mathrm{GFP}^{+}$cells exhibited a range of action potential-like waves in response to depolarizing current pulses (Fig. $3 d-h$ ). Early in development (P9), the majority of $\mathrm{I}_{\mathrm{Na}}{ }^{+} \mathrm{GFP}^{+}$cells $(69$ of 87 ) in both gray and white matter showed a single regenerative depolarization (Fig. $3 d-f$ ). Single action potential-like events were also detected in 21 of $37 \mathrm{I}_{\mathrm{Na}}{ }^{+} \mathrm{GFP}^{+}$cells in the white and gray matter later in development (P33). A minority of $\mathrm{I}_{\mathrm{Na}}$-expressing cells (3 of 124) exhibited repetitive action potential-like waves on depolarization (Fig. $3 g, h$ ). Similar regenerative responses have been reported for OPCs in white (Chittajallu et al., 2004; De Biase et al., 2010) and gray (Chittajallu et al., 2004; Ge et al., 2009; De Biase et al., 2010) matter regions of the postnatal mouse brain.

Although $\mathrm{I}_{\mathrm{Na}}{ }^{+} \mathrm{GFP}^{+}$cells could generate action potentiallike events, they were not like typical neuronal action potentials or those described for $\mathrm{I}_{\mathrm{Na}}{ }^{+}$OPCs in the rat cerebellar white matter (Káradóttir et al., 2008). The action potential-like events had a higher threshold for activation $(-21 \pm 1.5 \mathrm{mV})$ than action potentials in neurons, their amplitudes increased somewhat with larger current injections (Fig. $3 d-f$ ) unlike neuronal action potentials, and the timescale of the spikes $(4.3 \pm 0.7 \mathrm{~ms}$, measuring the duration at half of the amplitude) was longer than those for most neurons (for examples, see Fig. $3 d-h$ ). This probably reflects the lower ratio of $\mathrm{I}_{\mathrm{Na}}$ current magnitude to cell input resistance in mouse OPCs (mean peak inward current of $<300 \mathrm{pA}$; see Fig. 5k) than was found previously for rat OPCs (mean peak inward current of $\sim 1000$ pA; Káradóttir et al., 2008) and suggests that mouse $\mathrm{I}_{\mathrm{Na}}{ }^{+}$cells do not have a sufficient density of $\mathrm{I}_{\mathrm{Na}}$ to fire bona fide action potentials.

As $\mathrm{I}_{\mathrm{Na}}{ }^{+} \mathrm{GFP}^{+}$cells were detected in all brain regions, including the white matter of the CC, it seemed unlikely that the excitability of the $\mathrm{I}_{\mathrm{Na}}{ }^{+} \mathrm{GFP}^{+}$cells analyzed was a result of ectopic GFP
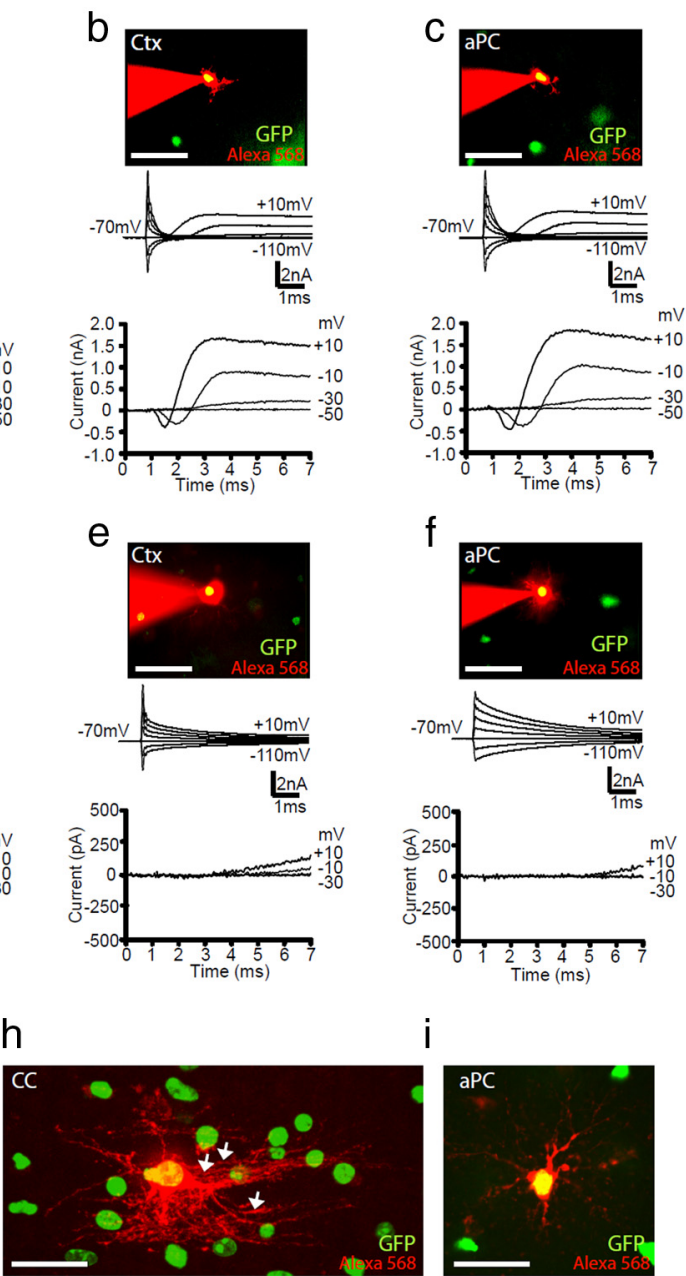

Figure 2. Two types of $\mathrm{GFP}^{+} \mathrm{OL}$ lineage cells in the postnatal mouse brain. $\boldsymbol{a}-\boldsymbol{f}$, Cells expressing GFP driven by the $P d g f r \alpha$ promoter (green) were whole-cell patch clamped and filled with Alexa Fluor-568 dye (red) (top image in columns $\boldsymbol{a}-\boldsymbol{f}$ ). Current (second panel of $\boldsymbol{a}-\boldsymbol{f}$ ) were recorded for GFP ${ }^{+}$cells with and without $\mathrm{I}_{\mathrm{Na}}$ ( $\boldsymbol{a}-\boldsymbol{c}$ and $\boldsymbol{d} \boldsymbol{- \boldsymbol { f }}$, respectively), to voltage steps morphology in white and gray matter [e.g., dye-filled GFP ${ }^{+}$cells in the $C(\boldsymbol{g})$ and aPC $(\boldsymbol{i})$ ], but GFP could also be occasionally detected in cells that were more advanced in their differentiation with more 0 L-like morphology, including myelinating internodes (e.g., dye-filled GFP ${ }^{+}$cell in the C(; $\boldsymbol{h}$ ). White arrows indicate myelin internodes. Scale bars: $\boldsymbol{a}-\boldsymbol{f}, 50 \mu \mathrm{m} ; \boldsymbol{g}-\boldsymbol{i}, 30 \mu \mathrm{m}$.

expression by immature neurons or cortical interneurons. However, because some OPCs reportedly express immature neuronal markers, such as TOAD-64 (turned on after division-64), DCX, Tuj1, and HuC/D (Belachew et al., 2003; Chittajallu et al., 2004; Tamura et al., 2007), suggesting that they might turn into neurons in various brain regions (for review, see Richardson et al., 2011), we investigated this possibility by immunolabeling coronal brain sections from P9 and P33 Pdgfr $\alpha-G F P$ transgenic mice to detect GFP and a variety of neuronal markers (Fig. 4). At both ages, $\mathrm{GFP}^{+}$cells in the Ctx were negative for the expression of parvalbumin (Fig. 4a,m), SST (Fig. 4b,m), NPY (Fig. 4c,m), calbindin (Fig. $4 d, m$ ), reelin (Fig. $4 e, m$ ), and PSA-NCAM (Fig. $4 l, m)$. Although the vast majority of $\mathrm{GFP}^{+}$cells were also negative for calretinin (Fig. 4f,m) and NeuN (Fig. 4i,m), a small number of cells that exhibited faint GFP expression were found to express calretinin (Fig. $4 g, h, m$ ) or NeuN (Fig. $4 j, k, m$ ) strongly and so are presumed to be neurons. In the Ctx, these presumptive neurons were located in the superficial cortex, concentrated near the brain midline. Even if the calretinin ${ }^{+}$and $\mathrm{NeuN}^{+} \mathrm{GFP}^{+}$cells 
a
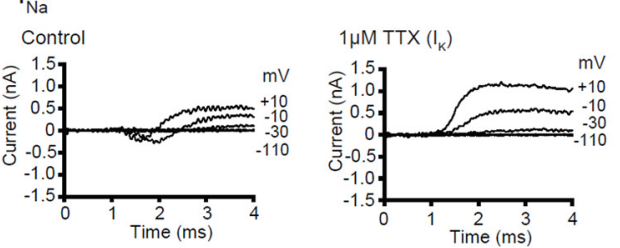

b no I

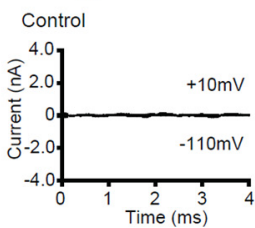

d

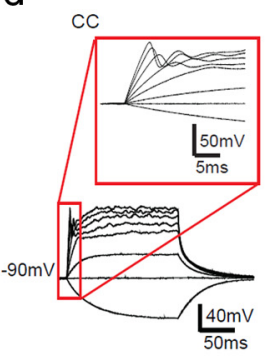

g

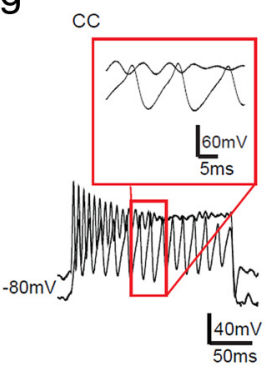

$I_{\mathrm{Na}}$ (minus $I_{\mathrm{K}}$ )

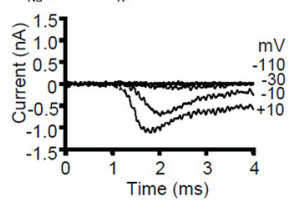

C

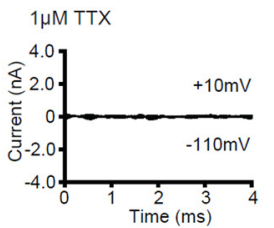

e

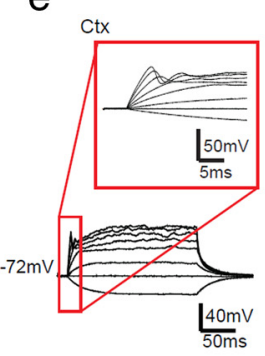

$\mathrm{h}$

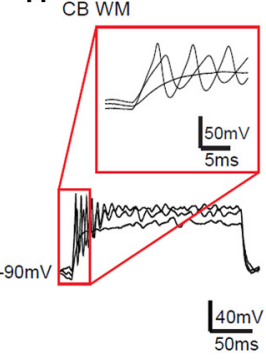

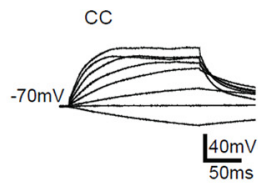

f

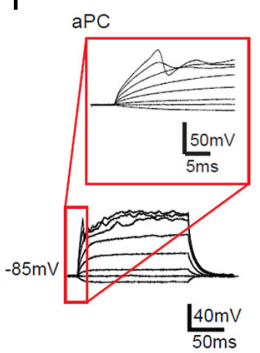

Figure 3. $\mathrm{I}_{\mathrm{Na}}{ }^{+} \mathrm{GFP}+$ cells generate action potential-like events in response to current injection. $\boldsymbol{a}$, Left, Capacity transient and ohmic leak-subtracted responses of a GFP ${ }^{+}$cell with $\mathrm{I}_{\mathrm{Na}}$ to voltage steps in $20 \mathrm{mV}$ increments from $-70 \mathrm{mV}$. Middle, TTX at $1 \mu \mathrm{M}$ blocked the $\mathrm{I}_{\mathrm{Na}}$. Right, Subtracting the voltage-gated $\mathrm{I}_{\mathrm{K}}$ isolated in TTX from the total voltage-gated current gave the voltage-gated $\mathrm{Na}^{+}$current. $\boldsymbol{b}$, Left, Capacity transient and ohmic leak-subtracted responses of a GFP ${ }^{+}$cell without $\mathrm{I}_{\mathrm{Na}}$ to voltage steps in increments of $20 \mathrm{mV}$ (to -110 to $+10 \mathrm{mV}$ ) from $-70 \mathrm{mV}$. Right, TTX did not change the response of the cell to voltage steps. Traces representative of three $\mathrm{GFP}^{+}$cells without $\mathrm{I}_{\mathrm{Na}}$ are shown. $\mathbf{c}-\boldsymbol{f}$, Responses of white and gray matter GFP ${ }^{+}$cells to depolarizing current injection (-20,0,20,60,100,160,220, and $260 \mathrm{pA}$ of current was injected).c, Current-clamp recording of a GFP ${ }^{+}$ cell without $\mathrm{I}_{\mathrm{Na}}$ at $\mathrm{Pg}$, in the $\mathrm{CC}$; similar responses were seen in all other brain areas examined. $\boldsymbol{d}-\boldsymbol{f}$, Current-clamp recordings for $\mathrm{GFP}^{+}$cells with $\mathrm{I}_{\mathrm{Na}}$, at $\mathrm{P} 9$, in the $\mathrm{CC}(\boldsymbol{d}), \mathrm{Ctx}(\boldsymbol{e})$, and aPC $(\boldsymbol{f}) \cdot \boldsymbol{g}, \boldsymbol{h}$, Current-clamp recordings from GFP ${ }^{+} \mathrm{I}_{\mathrm{Na}}$ cells, which produced repetitive action potential-like waves in the $C($ at $\mathrm{P3} 3$ (40, $140 \mathrm{pA}$ of current was injected) $(\boldsymbol{g})$ and cerebellar white matter (CB WM) at $P 9(40,80,120 \mathrm{pA}$ of current was injected) (h). Red boxes indicate the region of the trace that has been enlarged.

are separate populations, at $\mathrm{P} 33$, they would together still comprise only $\sim 2 \%$ (and $\sim 4 \%$ at P9) of all $\mathrm{GFP}^{+}$cells. Consistent with our findings in the Ctx, $\mathrm{GFP}^{+}$cells in the aPC of P33 $P d g f r \alpha-G F P$ transgenic mice rarely expressed neuronal markers: a small number colabeled for PSA-NCAM $\left(4\right.$ of $1820 \mathrm{GFP}^{+}$cells

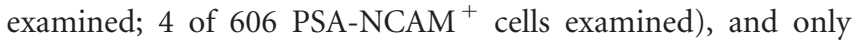
$0.7 \pm 0.2 \%$ of $\mathrm{GFP}^{+}$cells coexpressed NeuN.

Our finding that GFP (driven by an OL lineage cell promoter) is expressed by a small number of neuronal cells is reminiscent of a study from Belachew et al. (2003), who suggested that the brightly labeled $\mathrm{GFP}^{+} \mathrm{NG}^{+}$OPCs that they observed in CNPase-GFP transgenic mice were able to generate faintly labeled $\mathrm{GFP}^{+}$interneurons in the postnatal mouse hippocampus. Our data might suggest either that some interneurons are gener- ated from OPCs and the GFP fluorescence is residual and indicative of their origin, or that a small subset of cortical neurons have a very low level of $P d g f r \alpha$ promoter activity.

By counting the number of neurons labeled for calretinin and NeuN, we deduced that the GFP-labeled cells account for $11 \pm 0.7 \%$ of calretinin ${ }^{+}$and $0.14 \pm$ $0.02 \%$ of $\mathrm{NeuN}^{+}$neurons in the Ctx at P9 and $14 \pm 2 \%$ of calretinin ${ }^{+}$and $0.2 \pm$ $0.02 \%$ of $\mathrm{NeuN}^{+}$neurons in the Ctx at P33. The $\mathrm{GFP}^{+}$neurons expressed extremely low levels of GFP that was approximately eight times lower in intensity (averaged over the nucleus) than was detected in $\mathrm{NG}^{+}$OPCs (neurons, $10.6 \pm 1$ arbitrary units; OPCs, $84.3 \pm 0.1$ arbitrary units) and approximately three times less than was detected in NG2 ${ }^{\text {neg }}$ OLs $(35 \pm 5$ arbitrary units). The $\mathrm{GFP}^{+}$neurons were difficult to detect even by antibody labeling, so it is highly unlikely that they would have been selected for patch clamping based on their intrinsic GFP fluorescence. Additionally, patch-clamp recordings were performed in brain hemisections; therefore, cells immediately bordering the cortical midline were not targeted, and the calretinin $^{+}$and $\mathrm{NeuN}^{+}$cells were too few in number $(<5 \%)$ to account for the significant number of $\mathrm{GFP}^{+}$cells that we classify as excitable $\mathrm{I}_{\mathrm{Na}}{ }^{+} \mathrm{GFP}^{+}$cells (77 and $61 \%$ of the $\mathrm{GFP}^{+}$cells that were studied expressed $\mathrm{I}_{\mathrm{Na}}$ in the Ctx at $\mathrm{P} 9$ and $\mathrm{P} 33$, respectively).

\section{All GFP ${ }^{+}$cells that express NG2 strongly are proliferative and express $\mathrm{I}_{\mathrm{Na}}$}

Based on GFP expression, we were able to identify OL lineage cells, but, as described above, we found that they were heterogeneous in terms of $\mathrm{I}_{\mathrm{Na}}$ expression in all brain regions examined. The morphology of the Alexa Fluor-568-filled cells suggested that the expression of $\mathrm{I}_{\mathrm{Na}}$ might be an OPC trait, whereas a lack of $\mathrm{I}_{\mathrm{Na}}$ might be an OL trait. Morphology proved to be more useful for identifying putative OPCs in the white matter than in the gray matter. In white matter, $\mathrm{GFP}^{+}$cells with OPC-like morphology (Fig. $2 g$ ) $\left(\mathrm{I}_{\mathrm{Na}}{ }^{+} \mathrm{GFP}^{+}\right.$cell) could be easily distinguished from OLs with myelinating processes (Fig. $2 h, \mathrm{I}_{\mathrm{Na}}{ }^{\text {neg }} \mathrm{GFP}^{+}$cell). OPCs were defined as having bipolar or stellate morphology and OLs as having multiple long processes aligned with axons. This distinction was less obvious in gray matter (Fig. $2 i, \mathrm{I}_{\mathrm{Na}}{ }^{\text {neg }} \mathrm{GFP}^{+}$, cell), because axons do not fasciculate in gray matter as they do in white matter tracts, and myelin internodes are not parallel with one another but oriented in all directions (Murtie et al., 2007; Vinet et al., 2010). Consequently, in the gray matter, some $\mathrm{GFP}^{+}$differentiated OLs might easily be mistaken for OPCs. To identify OPCs unambiguously in both gray and white matter, it was necessary to perform postrecording immunohistochemistry for NG2. 


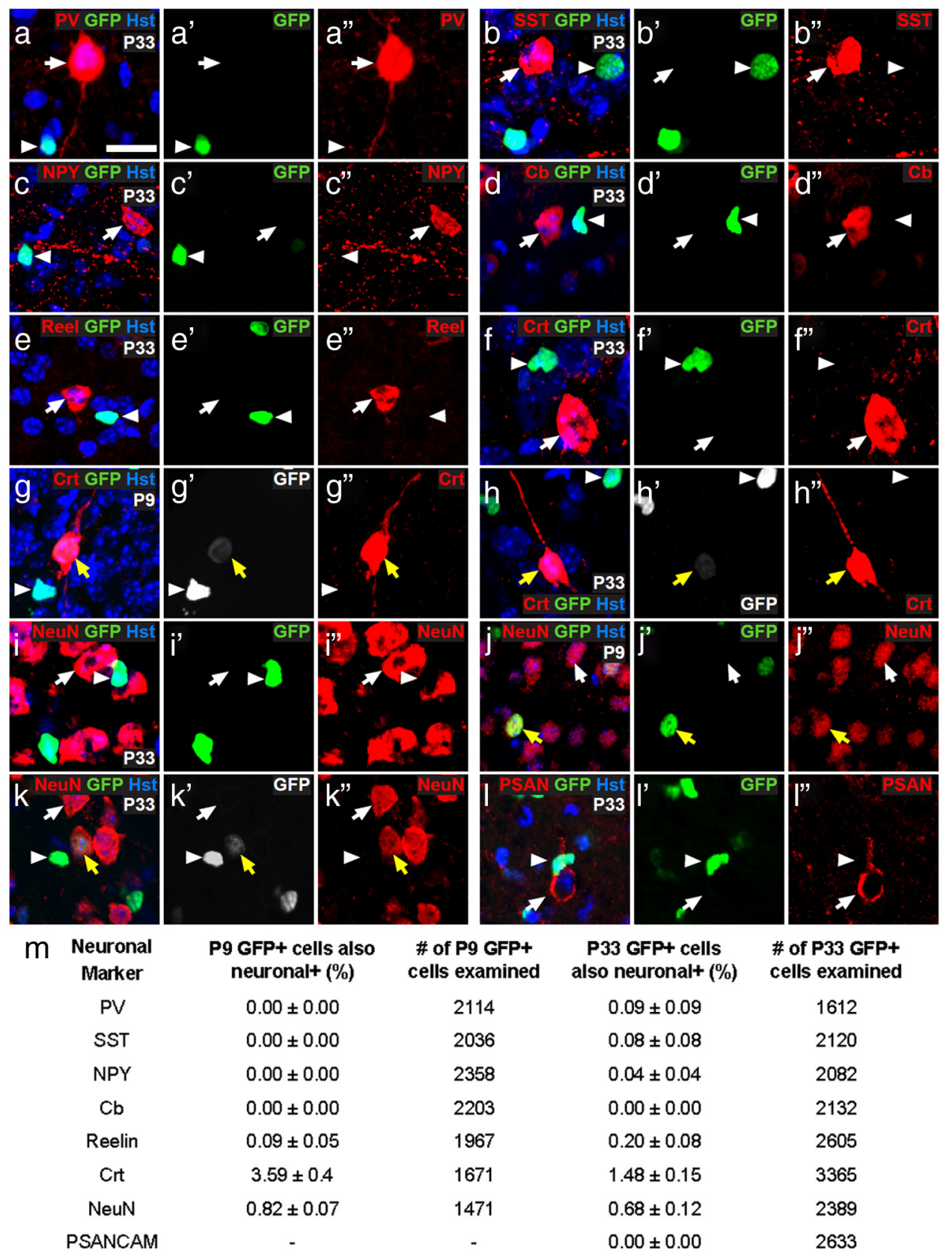

Figure 4. A small proportion of calretinin ${ }^{+}$interneurons express GFP in the medial motor Ctx of Pdgfr $\alpha$-GFP transgenic mice. $a-I$, Cryosections from P9 and P33 Pdgfr $\alpha$-GFP transgenic mice were costained to detect GFP (green) and a variety of neuronal markers (red): parvalbumin (PV; $\boldsymbol{a}), \operatorname{SST}(\boldsymbol{b})$, NPY (c), calbindin (cb; $\boldsymbol{d})$, reelin (e), calretinin (crt; $\boldsymbol{f}-\boldsymbol{h})$, NeuN (i- $\boldsymbol{k})$, and PSA-NCAM (I). $\boldsymbol{m}$, The number of single-labeled GFP ${ }^{+}$cells (white arrowheads), single-labeled neuronal cells (white arrows), and colabeled cells (yellow arrows) was counted. The table gives the proportion of $\mathrm{GFP}^{+}$cells that coexpressed any of the neuronal markers. This was quantified in the Ctx for three mice and is expressed as the average percentage \pm SEM. The total number of GFP ${ }^{+}$cells examined is also given. The only neuronal markers expressed by subsets of cortical GFP ${ }^{+}$cells were calretinin and NeuN. Scale bars: $\boldsymbol{a}, \boldsymbol{c}-\boldsymbol{e}, \boldsymbol{h}, \boldsymbol{j}-\boldsymbol{I}, 15 \mu \mathrm{m} ; \boldsymbol{b}, \boldsymbol{f}, \boldsymbol{g}, \boldsymbol{i}, 10 \mu \mathrm{m}$.

Individual $\mathrm{GFP}^{+}$cells in the $\mathrm{CC}$, $\mathrm{Ctx}$, and aPC were wholecell patch clamped to determine whether or not they exhibited $\mathrm{I}_{\mathrm{Na}}$ and then dye filled with Alexa Fluor-568. Dye filling not only revealed the cellular morphology but also permitted identification of the recorded cell after NG2 immunolabeling. Three categories of dye-filled cells were identified: (1) cells expressing NG2 strongly ( $\mathrm{NG}_{2}{ }^{+}$cells) that we define to be OPCs (Fig. 5a,c,e), (2) cells expressing low levels of NG2 limited to the soma or the base of some processes ( $\mathrm{NG} 2^{\text {low }}$ cells) that were presumed to be early differentiating OLs (Fig. $5 g$ ), and (3) cells with no detectable NG2 (NG2 ${ }^{\text {neg }}$ cells) that were assumed to be OLs (Fig. 5i).
At both $\mathrm{P} 9$ and $\mathrm{P} 33$ and in all brain regions examined, we found that the $\mathrm{NG}_{2}{ }^{+} \mathrm{GFP}^{+}$cell population was the same as the population of $\mathrm{I}_{\mathrm{Na}}^{+} \mathrm{GFP}^{+}$excitable cells (Fig. 5b,d,f). As expected, these $\mathrm{NG}^{+}{ }^{+} \mathrm{I}_{\mathrm{Na}}{ }^{+}$presumed OPCs were found to coexpress PDGFR $\alpha$ (five cells examined in the Ctx and seven cells in the aPC), confirming them as OPCs. The magnitude of the net inward current generated by OPCs on depolarization from -70 to $10 \mathrm{mV}$ was $\sim 130-320 \mathrm{pA}$ in all areas (Fig. $5 k$ ) and decreased with age, falling by 21,61 , or $31 \%$ from P9 to P33 in the CC, Ctx, or aPC, respectively (Fig. $5 k$ ). Similarly, in all brain areas, a reduction in membrane resistance (Fig. $5 l$ ) and peak outward current (Fig. 5n) was observed with age, whereas no consistent 
a
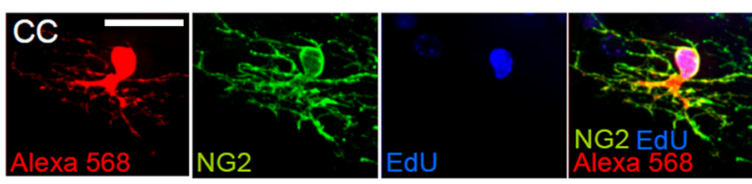

C
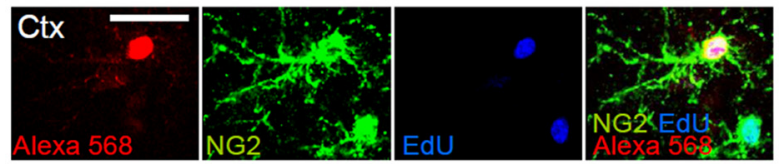

e

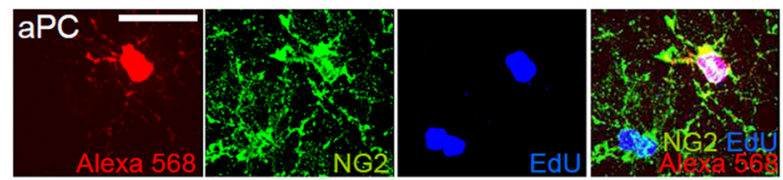

g

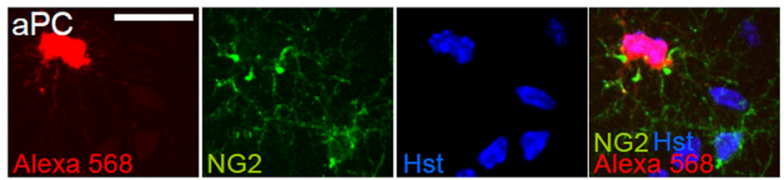

i
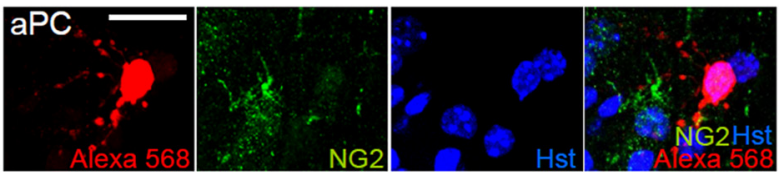

b

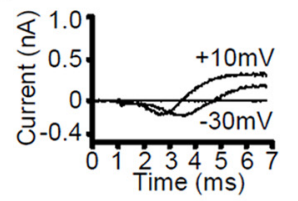

d

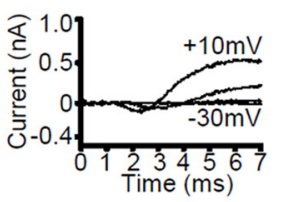

f

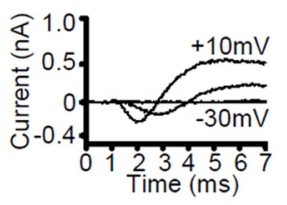

h

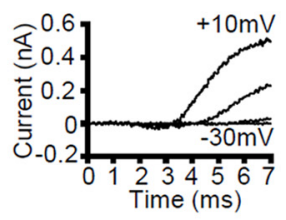

j

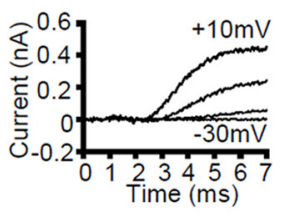

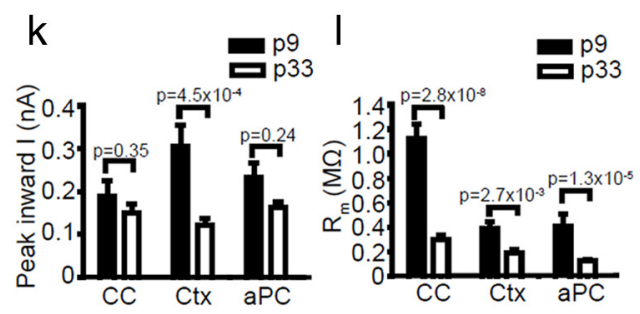
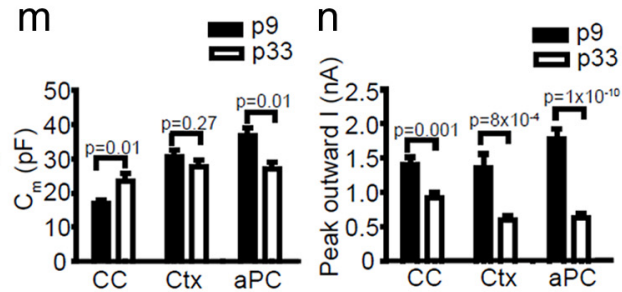

Figure 5. All brain NG2 ${ }^{+} \mathrm{OPCs}$ express $\mathrm{I}_{\mathrm{Na}}$ and proliferate. $\boldsymbol{a}-\boldsymbol{j}$, Images of dye fills of whole-cell patch-clamped GFP ${ }^{+}$cells in CC, Ctx, and aPC (red) and labeling for NG2 (green) and EdU [or Hoechst 33258 (Hst) in $\boldsymbol{g}, \boldsymbol{i}$ ] (blue) (left), together with current responses to depolarizing voltage steps in $20 \mathrm{mV}$ increments from $-70 \mathrm{mV}$ (right). Cells fell into one of three main groups: $\boldsymbol{a}-\boldsymbol{f}$,

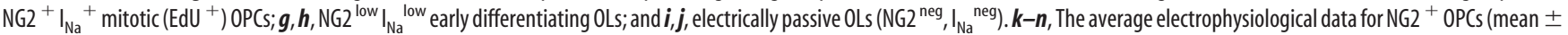
SEM) at P9 (CC, $n=20 ; \mathrm{Ctx}, n=15 ; \mathrm{aPC}, n=14$ cells) and P33 (CC, $n=22 ; \mathrm{Ctx}, n=17 ; \mathrm{aPC}, n=41$ cells) are shown, including the following: $\boldsymbol{k}$, peak inward current on depolarization from - 70 to $+10 \mathrm{mV} ; \boldsymbol{I}$, membrane resistance at $-70 \mathrm{mV} ; \boldsymbol{m}$, membrane capacitance; and $\boldsymbol{n}$, peak outward current (on depolarization from -70 to $+10 \mathrm{mV}$ ). Scale bars, $20 \mu \mathrm{m}$.

change in cell capacitance (a measure of cell size) could be detected with age (Fig. $5 \mathrm{~m}$ ). OPCs were consistently larger in gray matter than in white matter, regardless of age (Fig. $5 \mathrm{~m}$ ). The resting membrane potential of OPCs ranged from between approximately -85 and $-94 \mathrm{mV}$ : at $\mathrm{P} 9$, the resting potential of OPCs was $-94 \pm 3.8,-93 \pm 2.6$, and $-92 \pm 1.6 \mathrm{mV}$ in the CC $(n=14), \operatorname{Ctx}(n=14)$, and aPC $(n=10)$, respectively, whereas at $\mathrm{P} 33$, the resting potential of OPCs was $-89 \pm 1.9,-86 \pm 3.3$, and $-85 \pm 2.3 \mathrm{mV}$ in the CC $(n=22), \operatorname{Ctx}(n=18)$, and aPC $(n=$ 17 ), respectively. These data suggest that the intrinsic membrane properties of OPCs are subject to change during development, but $\mathrm{I}_{\mathrm{Na}}$ expression is a universal property of OPCs in all brain areas throughout postnatal life.

The second category of $\mathrm{GFP}^{+}$cells, $\mathrm{NG} 2^{\text {low }}$ cells, had limited expression of NG2 (Fig. 5g). These cells had little to no $\mathrm{I}_{\mathrm{Na}}$ (Fig.
$5 h$; mean net inward current, $24 \pm 5 \mathrm{pA}$ in nine cells) so we refer to these as NG2 ${ }^{\text {low }} \mathrm{I}_{\mathrm{Na}}$ low cells. We assume that they correspond to early differentiating OLs that are downregulating their $\mathrm{I}_{\mathrm{Na}}$ and NG2 expression, as described previously (De Biase et al., 2010; Kukley et al., 2010), and are similar to the $\mathrm{NG}^{+} \mathrm{I}_{\mathrm{Na}}$ negative cells reported in rat cerebellum by Káradóttir et al. (2008). The final category of $\mathrm{GFP}^{+}$cells (NG2 ${ }^{\text {neg }}$ OLs) lacked both NG2 labeling (Fig. 5I) and $\mathrm{I}_{\mathrm{Na}}$ expression (Fig. 5j) and therefore correspond to premyelinating or myelinating OLs ( 44 cells; $\mathrm{NG}^{\text {neg }} \mathrm{I}_{\mathrm{Na}}{ }^{\text {neg }} \mathrm{OLs}$ ), which we refer to collectively as OLs.

A number of studies have indicated the presence of a postmitotic population of OPCs (defined by NG2 immunolabeling) within the postnatal mouse brain (for review, see Richardson et al., 2011). In the piriform cortex, these postmitotic OPCs have been suggested to comprise a substantial fraction of the OPC 
population and to differentiate over time, providing a source of new projection neurons (Rivers et al., 2008; Guo et al., 2010). To assess the electrophysiological properties of dividing oligodendrogenic OPCs and the nondividing putative neurogenic OPCs, we administered the thymidine analog EdU to Pdgfr $\alpha-G F P$ mice for $5 \mathrm{~d}$ before making patch-clamp recordings at $\mathrm{P} 9$ and for 12-13 $\mathrm{d}$ before making patch-clamp recordings at P33. In addition to NG2 immunolabeling, slices were processed to detect EdU. These dosing regimens were selected to label the proliferating OPCs in the white and gray matter of the brain, which were predicted from Psachoulia et al. (2009) to be approximately half of all OPCs. Unexpectedly, given this prediction, the vast majority of $\mathrm{GFP}^{+}$, $\mathrm{NG} 2{ }^{+}, \mathrm{I}_{\mathrm{Na}}{ }^{+}$OPCs that we analyzed were $\mathrm{EdU}^{+}$, regardless of brain region or age. At $\mathrm{P} 9, \sim 90 \%$ of $\mathrm{NG}^{+} \mathrm{I}_{\mathrm{Na}}{ }^{+} \mathrm{OPCs}$ had divided in the previous 5 days (Ctx, 8 of 9 OPCs; CC, 12 of 13 OPCs). At P33, 70-100\% of all GFP ${ }^{+}, \mathrm{NG}^{+}{ }^{+}, \mathrm{I}_{\mathrm{Na}}{ }^{+}$OPCs were EdU labeled in all regions (Ctx, 17 of 24 OPCs; CC, 4 of 4 OPCs; aPC, 29 of 31 OPCs) (Fig. $5 a-f$ ). In contrast, none of the NG2 ${ }^{\text {low }}$ $\mathrm{I}_{\mathrm{Na}}{ }^{\text {low }}$ cells analyzed in the Ctx of P33 mice (after $\sim 13 \mathrm{~d}$ of EdU administration) had incorporated EdU (nine cells analyzed), consistent with in vitro data from Sugiarto et al. (2011), who suggested that, after an asymmetric OPC division, one cell begins to downregulate mitogenic receptors, commits to differentiating, and will no longer incorporate BrdU, whereas the other retains the expression of mitogenic receptors, remains an OPC, and reenters the cell cycle. This supports the idea that the $\mathrm{NG} 2{ }^{\text {low }} \mathrm{I}_{\mathrm{Na}}$ low cells are early differentiating OLs, formed from a cell division that occurred $>13 \mathrm{~d}$ earlier. The large fraction of individual OPCs that were $\mathrm{EdU}^{+}$after patch-clamp recordings accurately reflected the total fraction of EdU ${ }^{+}$OPCs quantified in each brain region when confocal analysis was performed on large numbers of OPCs immunolabeled for NG2. In Ctx at P9, $90 \pm 2 \%$ of $\mathrm{NG}_{2}{ }^{+} \mathrm{OPCs}$ were $\mathrm{EdU}^{+}$, and, at P33, $83 \pm 1 \%$ of $\mathrm{NG} 2^{+} \mathrm{OPCs}$ were $\mathrm{EdU}^{+}$, indicating that the high fraction of OPCs identified as proliferating was not the result of a cell-selection bias when patch clamping but instead indicated that a larger proportion of OPCs underwent cell division than was detected previously by Psachoulia et al. (2009) and Guo et al. (2010).

These data undermine previous reports, based on cumulative BrdU labeling of dividing OPCs in wild-type mice, which concluded that there is a postmitotic population of OPCs in the brain (Rivers et al., 2008; Psachoulia et al., 2009; Guo et al., 2010; Simon et al., 2011). This in turn raises questions about the origin of new projection neurons that accumulate in the piriform cortex of adult $P d g f r \alpha-C r e E R^{T 2}: R 26 R-Y F P$ and $P l p-C r e E R^{T 2}: R 26 R-Y F P$ transgenic mice but do so without incorporating BrdU even after long labeling periods and thus are unlikely to be derived from dividing progenitors (Rivers et al., 2008; Guo et al., 2010). However, our EdU labeling experiments on Ctx described above left open the possibility that there might be a local population of postmitotic OPCs specifically in the aPC. To test this, we administered EdU to P21 and P60 mice via their drinking water for various time periods up to $35 \mathrm{~d}$. Coronal brain sections were immunolabeled for PDGFR $\alpha$ and NG2 to detect OPCs and were costained for EdU (Fig. 6a). When administering EdU from P21, we found that the proportion of OPCs in the aPC that became $\mathrm{EdU}^{+}$increased linearly with time $\left(r^{2}>0.96\right)$ at a rate of $7.6 \%$ per day, until $>98 \%$ of all OPCs were stably labeled after $\sim 13 \mathrm{~d}$ (Fig. 6b). From P60, we found that the fraction of EdU-labeled OPCs increased linearly with time $\left(r^{2}>0.97\right)$ at a rate of $3.15 \%$ per day until $>98 \%$ of OPCs were labeled after $\sim 30 \mathrm{~d}$. From these data, we were able to calculate the cell-cycle time for OPCs in the aPC as being $\sim 12.9 \pm 0.8 \mathrm{~d}$ at P2 1 and $31.3 \pm 1.7 \mathrm{~d}$ at P60 (using
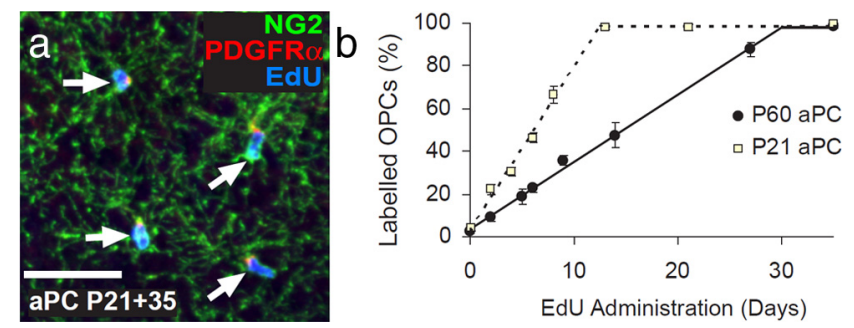

Figure 6. All NG2 ${ }^{+} \mathrm{OPCs}$ in the $\mathrm{aPC}$ proliferate and incorporate EdU. $\boldsymbol{a}$, Coronal brain sections containing the aPC immunolabeled to detect PDGFR $\alpha$ (red) and NG2 (green) to identify OPCs and then developed to visualize EdU incorporation (blue). $\boldsymbol{b}$, The proportion of OPCs $\left(\right.$ PDGFR $\left.\alpha^{+} \mathrm{NG2}^{+}\right)$that had incorporated EdU as a function of EdU administration time (mean $\pm \mathrm{SEM}, n=3$ mice for each time point). Scale bar, $35 \mu \mathrm{m}$.

the methods described by Psachoulia et al., 2009). These data show that all OPCs (defined by strong NG2 and PDGFR $\alpha$ expression) in the aPC are mitotically active, as in other regions of the forebrain.

\section{OPCs generate exclusively OLs in the postnatal mouse brain}

To determine what cell types are produced by OPCs in the CC, Ctx, and aPC, we labeled and traced the fates of OPCs using two cell tracing methods simultaneously: (1) extended EdU exposure to label all proliferating cells (including all OPCs and their differentiating progeny) and (2) Cre-lox fate mapping using $P d g f r \alpha-$ $C r e E R^{T 2}$ mice. EdU was administered via the drinking water to $P d g f r \alpha-C r e E R^{T 2}: R 26 R-Y F P$ mice continuously after P25 to prelabel all proliferating OPCs. Tamoxifen was administered to these same mice on 4 consecutive days ( $\mathrm{P} 45-\mathrm{P} 48$ inclusive) to activate Cre recombination and induce YFP expression in PDGFR $\alpha$-positive OPCs (see experimental time line in Fig. 7a).

The identity of the starting population of YFP-labeled cells was confirmed by immunolabeling sections of $P d g f r \alpha-C r e E R^{T 2}$ : $R 26 R-Y F P$ mouse brains at P45 + 6, 2 days after the final dose of tamoxifen. Sections were immunolabeled for YFP and different combinations of OLIG2, NG2, PDGFR $\alpha$, PSA-NCAM, NeuN, or the microglial marker Iba1 (Fig. $7 b$ ). In the aPC, $\sim 90 \%$ of all $\mathrm{YFP}^{+}$cells colabeled for OLIG2 $\left(>500 \mathrm{YFP}^{+}\right.$cells counted), most of which were OPCs, because $88 \pm 4 \%$ of $\mathrm{YFP}^{+}$cells also colabeled for NG2 $\left(>600 \mathrm{YFP}^{+}\right.$cells counted) and $89 \pm 1 \%$ colabeled for PDGFR $\alpha\left(>400 \mathrm{YFP}^{+}\right.$cells counted). At P45 +6 , $<1 \%$ of $\mathrm{YFP}^{+}$cells in the aPC colabeled for NeuN $\left(>500 \mathrm{YFP}^{+}\right.$ cells counted). These data confirmed that tamoxifen induced the YFP labeling of OPCs and an insignificant number of $\mathrm{NeuN}^{+}$ neurons. In addition to OPCs, we also detected a population of $\mathrm{YFP}^{+} \mathrm{PSA}-N C A M^{+}$cells in the aPC (Fig. 7c), which constituted $11 \pm 6 \%$ of all $\mathrm{YFP}^{+}$cells $\left(>400 \mathrm{YFP}^{+}\right.$cells counted $)$. The YFP ${ }^{+}$ $\mathrm{PSA} \mathrm{NCAM}^{+}$cells were smaller than OPCs, having cell bodies $5.2 \pm 0.3 \mu \mathrm{m}$ in diameter compared with $10.1 \pm 0.5 \mu \mathrm{m}$ for $\mathrm{YFP}^{+} \mathrm{NG}^{+}$OPCs (20 cells measured in each case). Both the OPCs in the aPC and the very small $\mathrm{YFP}^{+} \mathrm{PSA}^{+} \mathrm{NCAM}^{+}$cells were found to express the microtubule-associated protein DCX (80 $\mathrm{NG}^{+}{ }^{+} \mathrm{OPCs}$ and $15 \mathrm{YFP}^{+}{ }^{+} \mathrm{PSA} \mathrm{NCAM}^{+}$cells examined) (Fig. $7 d$ ); however, the small $\mathrm{YFP}^{+}{\mathrm{PSA}-\mathrm{NCAM}^{+}}^{+}$cells were distinguishable from OL lineage cells in the same region because they did not express OLIG2 (Fig. 7e). Despite their small size, the $\mathrm{YFP}^{+} \mathrm{PSA}^{+} \mathrm{NCAM}^{+}$cells were not microglial cells because they did not express Ibal; indeed, no $\mathrm{YFP}^{+} \mathrm{Iba}^{+}$cells were found in the aPC $\left(>400 \mathrm{YFP}^{+}\right.$cells counted; Fig. $\left.7 b\right)$. Importantly, the $\mathrm{YFP}^{+} \mathrm{PSA}^{-N_{C A M}}{ }^{+}$cells did not become EdU labeled even when EdU was administered for $90 \mathrm{~d}$ (from P25 to P115; Fig. $7 l$ ). 

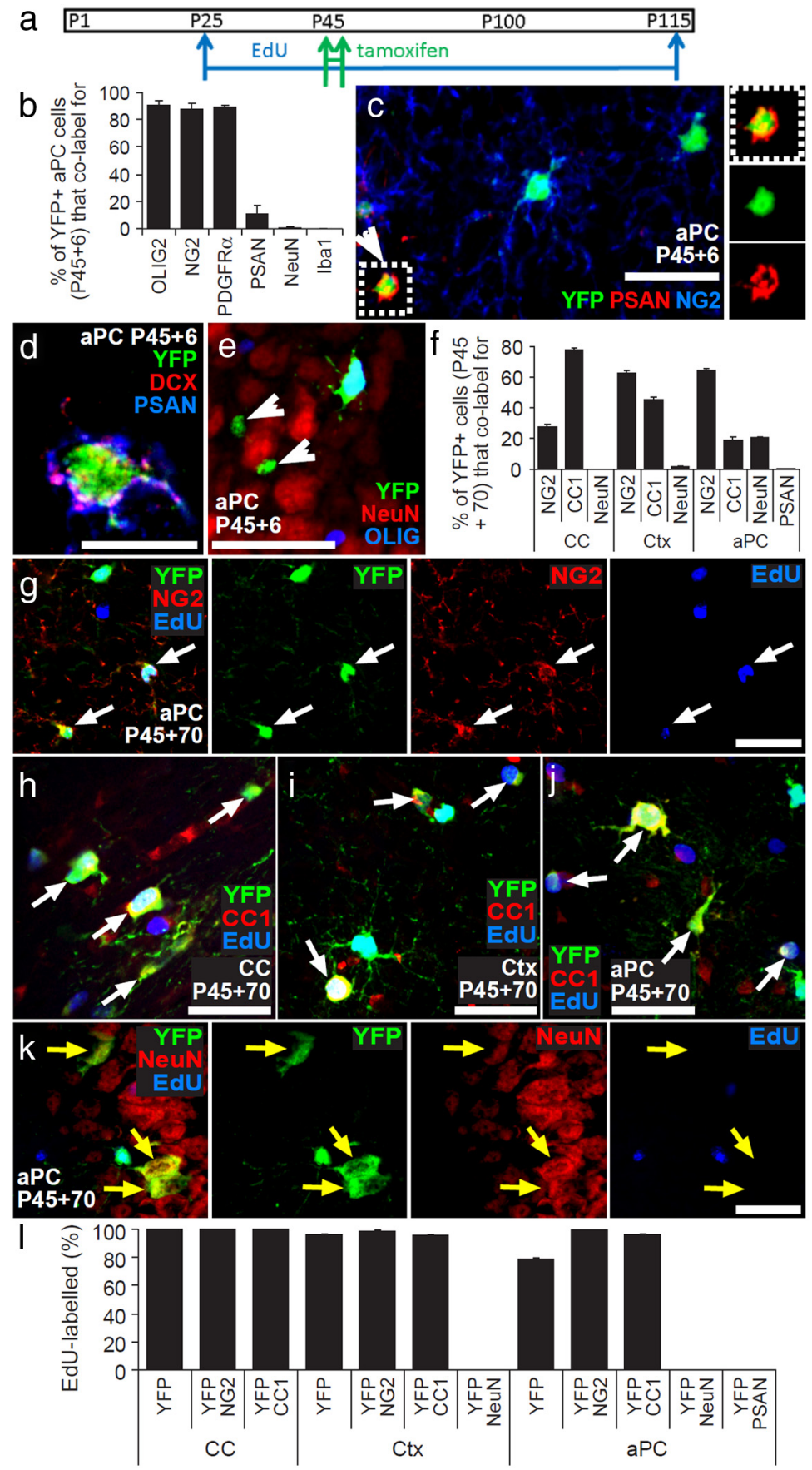

Figure 7. OPCs generate new $0 L$ s but not neurons in the postnatal mouse brain. $a, P d g f r \alpha-C r e E R^{T 2}: R 26 R-Y F P$ transgenic mice received EdU from P25, tamoxifen from P45 to P48, and were perfusion fixed at P115 $(P 45+70) \cdot \boldsymbol{b}$, Proportions of YFP ${ }^{+}$cells in aPC of P45 +6 Pdgfr $\alpha-C r e E R^{T 2}:$ R26R-YFP mouse brains that were OPCs $\left(\mathrm{NG}^{+}{ }^{+}\right), 0 \mathrm{Ls}\left(\mathrm{CC}^{+}\right)$, neuroblasts [PSA-NCAM ${ }^{+}$ $\left(\right.$ PSAN)], neurons $\left(\mathrm{NeuN}^{+}\right.$), or microglia $\left(\mathrm{Iba}^{+}{ }^{+}\right.$) (mean \pm SEM, $n=3$ mice). c, Immunolabeling of the aPC of P45 + 6 Pdgfr $\alpha-C r e E R^{T 2}$ : R26R-YFP transgenic mice for NG2 (blue), GFP (green), and PSA-NCAM (red). $\boldsymbol{d}$, A single-scan (1 $\left.\mu \mathrm{m}\right)$ confocal image through a cell in the aPC of P45 +6 Pdgfr $\alpha-C r e E R^{T 2}: R 26 R-Y F P$ transgenic mice that was immunolabeled for PSA-NCAM (blue), YFP (green), and DCX (red).e, Immunolabeling of the aPC of P45 + 6Pdgfr $\alpha-C r e E R^{T 2}: R 26 R-Y F P$ transgenic mice for 0LIG2 (blue), YFP (green), and NeuN (red). White arrowheads indicate unidentified YFP ${ }^{+}$cells in the aPC. $f$, Proportions of YFP ${ }^{+}$cells in the $\mathrm{CC}$, $\mathrm{Ctx}$, and aPC of P45 +70 Pdgfr $\alpha$ - $\mathrm{CreER}{ }^{T 2}:$ R26R-YFP mice that were OPCs $\left(\mathrm{NG2}^{+}\right)$, $0 \mathrm{Ls}\left(\mathrm{CC}^{+}\right)$, or neurons $\left(\mathrm{NeuN}^{+}\right)$ (mean $\pm \mathrm{SEM}, n=3$ mice) and proportion in aPC that were PSA-NCAM ${ }^{+} . \boldsymbol{g}$, Immunolabeling of the aPC for NG2 (red), GFP (green), and detection of EdU (blue). $\boldsymbol{h}$-j, Immunolabeling of the CC (h), Ctx (i), and aPC (j) for CC 1 antigen (red), GFP (green), and detection of EdU (blue). $\boldsymbol{k}$, Immunolabeling of the aPC for NeuN (red), GFP (green), and detection of EdU (blue). $\boldsymbol{I}$, Percentage of $\mathrm{YFP}^{+} \mathrm{OPCS}\left(\mathrm{YFP}^{+} \mathrm{NG}^{+}\right), \mathrm{YFP}^{+} \mathrm{OLS}\left(\mathrm{YFP}^{+} \mathrm{CC}^{+}\right)$, and $\mathrm{YFP}^{+}$neurons $\left(\mathrm{YFP}^{+} \mathrm{NeuN}^{+}\right)$that incorporated EdU (mean $\pm \mathrm{SEM}$ $n=3$ mice). White arrows indicate triple-labeled cells. Yellow arrows indicate double-positive but EdU-negative cells. Scale bars: $c, e-k, 30 \mu \mathrm{m} ; \boldsymbol{d}, 10 \mu \mathrm{m}$.
Therefore, OPCs are the only $\mathrm{EdU}^{+}$ $\mathrm{YFP}^{+}$double-labeled cells within the aPC, allowing us to follow their fate specifically in vivo.

$P d g f r \alpha-C r e E R^{T 2}: R 26 R-Y F P$ mice were labeled with EdU from P25, tamoxifen was administered from P45 to P48 (Fig. $7 a)$, and the mice were analyzed on P115 $(\mathrm{P} 45+70)$. Coronal brain sections were double immunolabeled for YFP and NG2 (OPCs), CC1 (OLs), or NeuN (neurons) (Fig. 7f). The sections were also processed to detect EdU. The vast majority of $\mathrm{YFP}^{+}$ cells in the CC and Ctx were OL lineage cells that expressed NG2 or CC1. However, as reported previously (Rivers et al., 2008), $\mathrm{YFP}^{+} \mathrm{NeuN}^{+}$neurons accumulated in the aPC in which they were about as numerous as $\mathrm{YFP}^{+}, \mathrm{CCl}^{+}$OLs (Fig. $7 f$ ). As expected, essentially all of the $\mathrm{YFP}^{+}$OPCs were $\mathrm{EdU}^{+}$in all brain regions examined (Fig. $7 g, l)\left(<2 \%\right.$ of YFP ${ }^{+}$ OPCs escaped EdU labeling). Therefore, all the differentiated progeny of $\mathrm{YFP}^{+}$ $\mathrm{EdU}^{+}$OPCs would be expected to inherit both markers. This was true for $\mathrm{YFP}^{+}$ $\mathrm{CC}^{+}$OLs in the CC, Ctx, and aPC, which were clearly also $\mathrm{EdU}^{+}\left(<4 \%\right.$ of $\mathrm{YFP}^{+}$ $\mathrm{CC}^{+}$OLs escaped EdU labeling) (Fig. $7 h-j, l)$, identifying them as cells that were generated from OPCs at some point between P45 and P115. However, this was not true for the $\mathrm{YFP}^{+} \mathrm{NeuN}^{+}$neurons that accumulated in the aPC over the same time period. None of the $\mathrm{YFP}^{+}$ $\mathrm{NeuN}^{+}$neurons had incorporated EdU (Fig. $7 k, l)\left(>1000 \mathrm{YFP}^{+}, \mathrm{NeuN}^{+}\right.$cells counted in five mice), indicating that they are not the progeny of YFP ${ }^{+}, \mathrm{EdU}^{+}$OPCs in the postnatal mouse brain. This suggests that the $\mathrm{YFP}^{+}{ }_{\mathrm{aPC}}$ neurons were generated after P45 (when tamoxifen was given) by direct differentiation of precursor cells, as yet unidentified, that had undergone their final division before P25 (i.e., before we administered EdU).

$\mathrm{YFP}^{+}$PSA-NCAM $^{+}$cells in the aPC are postmitotic cells that are born before P25

The $\mathrm{YFP}^{+}$EdU $^{\text {neg }}$ PSA-NCAM $^{+}$cells that we identified in the aPC of $\mathrm{P} 45+6$ $P d g f r \alpha-C r e E R^{T 2}: R 26 R-Y F P$ mice could be the source of the $\mathrm{YFP}^{+} \mathrm{EdU}^{\text {neg }}$ aPC neurons detected at $\mathrm{P} 45+70$. None of the rare $\mathrm{YFP}^{+} \mathrm{PSA}^{-\mathrm{NCAM}^{+}}$cells remaining in the aPC at $\mathrm{P} 45+70$ (Fig. $7 f$ ) were $\mathrm{EdU}^{+}$(Fig. $7 l$ ), indicating that, like the $\mathrm{YFP}^{+} \mathrm{NeuN}^{+}$cells, they were not the progeny of $\mathrm{YPP}^{+} \mathrm{EdU}^{+}$OPCs. In fact, no PSA-NCAM ${ }^{+}$cells detected in the aPC at any age had incorporated EdU $(>150$ $\mathrm{PSA}^{-\mathrm{NCAM}^{+}}$cells examined in three 
mice), indicating that they were born before EdU exposure began on P25. These cells were suggested previously to be an intermediate between OPCs and projection neurons, being generated by the direct differentiation of $\mathrm{DCX}^{+}$OPCs and retaining DCX expression (Guo et al., 2010). However, although our data indicate that both OPCs and the small $\mathrm{YFP}^{+}$

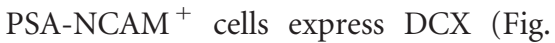
$7 d$ ), the small $\mathrm{YFP}^{+}$PSA-NCAM $^{+}$cells are actually a postmitotic population and so are not generated after P25 from proliferating OPCs or proliferating neural stem cells. At P45 +70 , PSA-NCAM ${ }^{+}$cells represented only $0.5 \pm 0.1 \%$ of all $\mathrm{YFP}^{+}$ cells within the aPC $\left(>1200 \mathrm{YFP}^{+}\right.$cells examined in $n=3$ mice; Fig. $7 f$ ). This fraction is 20 -fold less than at P45 +6 (Fig. $7 b$ ), reflecting their dilution by the accumulating number of $\mathrm{YFP}^{+} \mathrm{OLs}$ and neurons. From Rivers et al. (2008), we know that $\mathrm{YFP}^{+} \mathrm{NeuN}^{+}$cells are added to the aPC of Pdgfr $\alpha-C r e E R^{T 2}:$ R26R-YFP transgenic mice at a rate of $\sim 0.18$ cells per $30 \mu \mathrm{m}$ coronal brain section per day, starting from $30 \mathrm{~d}$ after tamoxifen administration. This equates to approximately seven $\mathrm{YFP}^{+}$neurons per section by $\mathrm{P} 45+$ $70[(70 \mathrm{~d}-30 \mathrm{~d}) \times 0.18$ per day $=7.2]$. In our study, the total number of YFP ${ }^{+}$PSA$\mathrm{NCAM}^{+}$cells per $30 \mu \mathrm{m}$ coronal brain section fell from approximately seven cells

per section at $\mathrm{P} 45+6$ to an average of approximately one cell per section at $\mathrm{P} 45+70$ (average number in 12 sections across three mice from each time point), which suggests that $\mathrm{YFP}^{+}$PSA$\mathrm{NCAM}^{+}$cells either die or differentiate over time. However, the fall of approximately six $\mathrm{YFP}^{+} \mathrm{PSA}^{-\mathrm{NCAM}^{+}}$cells per section can be seen to almost match the number of $\mathrm{YFP}^{+} \mathrm{NeuN}^{+}$neurons added to the $\mathrm{aPC}$ in the same timeframe.

\section{Discussion}

OPCs were originally assumed to be a homogeneous class of immature oligodendroglial cell but have since been subdivided according to their electrical properties (Chittajallu et al., 2004; Káradóttir et al., 2008), gene expression profiles (Gensert and Goldman, 2001; Mallon et al., 2002; Lin et al., 2009), proliferation rates (Psachoulia et al., 2009), response to injury (Keirstead et al., 1998; Lytle et al., 2009), and their abilities to differentiate into myelinating OLs (Mallon et al., 2002; Dimou et al., 2008) or other types of cells, including neurons (Rivers et al., 2008; Zhu et al., 2008; Guo et al., 2010). There continues to be much debate over how many subtypes of OPC there might be and the most appropriate way to classify them. To advance our understanding of this issue, we performed experiments examining both the histological and electrophysiological properties of OPCs and determined that all postnatal OPCs defined by strong expression of the NG2 proteoglycan (1) coexpress the mitogenic receptor $\operatorname{PDGFR} \alpha$, (2) express $\mathrm{I}_{\mathrm{Na}}$ and are electrically excitable, (3) are mitotically active and incorporate EdU, and (4) generate differentiated OLs but not neurons.

\section{OPCs in the postnatal mouse brain are excitable but do not fire action potentials}

Injecting current into OPCs led to action potential-like depolarization waves, consistent with previous studies in mice (Chittajallu et al., 2004; Ge et al., 2009; De Biase et al., 2010). These action potential-like waves differed from neuronal action potentials and the action potentials described previously for OPCs in the rat cerebellar white matter (Káradóttir et al., 2008), because they required a larger depolarization for activation, their amplitudes increased with larger current injections, and the timescale of the waves was longer. These regenerative events could be induced in OPCs in all brain areas and at all developmental stages investigated, suggesting they are a universal property of OPCs.

The likelihood that a cell will generate an action potential is determined by the magnitude of the voltage-gated sodium current and the cell membrane resistance (which can be adversely reduced by the conductance of the seal between the patch electrode and the cell membrane: Bakiri et al., 2009). Thus, the difference in spiking behavior we observed in mouse OPCs compared with rat OPCs (Káradóttir et al., 2008) might reflect the fact that mouse OPCs have a sixfold lower ratio of net inward current to membrane resistance than was found previously for rat $\mathrm{I}_{\mathrm{Na}}$ OPCs (Káradóttir et al., 2008). It is conceivable that, even in mouse OPCs, more robust spiking behavior would be observed in vivo in the absence of shunting by the seal between the patch electrode and the cell.

We observed significant variation among OPCs in the amount of current required to initiate $\mathrm{Na}^{+}$spikes (for the most excitable cells, the minimum current needed was $60 \mathrm{pA}$ ), in part reflecting differences in input resistances of the cells (Bakiri et al., 2009). 
White matter OPCs have been reported to receive $\sim 140$ synapses (Kukley et al., 2007), for each of which the miniature EPSC at the resting potential is $\sim 6 \mathrm{pA}$ (Kukley et al., 2007, 2010), implying that 10 simultaneous EPSCs would be needed to trigger this response in vivo $(60 \mathrm{pA} / 6 \mathrm{pA})$. This is likely to happen more frequently during development when synchronized neuronal firing occurs in the cortex (Mao et al., 2001), hippocampus (Mohns and Blumberg, 2008), cerebellum (Watt et al., 2009), and retina (Meister et al., 1991; Demas et al., 2003). However, whether or not full action potentials are produced by mouse OPCs in vivo, activation of their voltage-gated sodium channels is likely to amplify excitatory synaptic inputs, raising intracellular calcium levels to regulate OPC development, so the expression of $\mathrm{I}_{\mathrm{Na}}$ by OPCs might play a key role in regulating the developmental myelination of active circuits.

\section{Is excitability a regulator of OPC proliferation?}

All OPCs have $\mathrm{I}_{\mathrm{Na}}$, proliferate, and generate OLs in vivo (Figs. 5-7). However, the rate of OPC proliferation and OL production varies significantly between brain regions, with OPCs in the white matter dividing more rapidly than those in the gray matter (Power et al., 2002; Dimou et al., 2008; Rivers et al., 2008; Psachoulia et al., 2009; Simon et al., 2011). Many factors regulate OPC proliferation, such as PDGF-AA, basic fibroblast growth factor FGF2, and sonic hedgehog (Pringle et al., 1989; Collarini et al., 1992; Zhu et al., 1999). Furthermore, the expression of NG2 by OPCs has been reported to enhance ligand binding to PDGFR $\alpha$ and the fibroblast growth factor receptor (Goretzki et al., 1999). In the presence of growth factors, OPCs can proliferate in the absence of neurons (Collarini et al., 1992). However, there is evidence that neuronal activity also influences OPC proliferation in vivo. For example, injecting TTX into the eye, to block action potentials in retinal ganglion neurons, causes a large decrease in OPC proliferation in the optic nerve (Barres and Raff, 1993). This inhibitory effect of TTX could be alleviated by supplying exogenous PDGF to the optic nerve, suggesting that electrical activity stimulates release of PDGF within the nerve or enhances the responsiveness of OPCs to PDGF (Barres and Raff, 1993). There is other evidence that links growth factor signaling and electrical activity. PDGFR $\alpha$ signaling maintains the expression of delayed outward-rectifying $\mathrm{K}^{+}$channels by OPCs (Chittajallu et al., 2005), and block of $\mathrm{K}^{+}$channels as a consequence of glutamatergic signaling to OPCs inhibits their proliferation and lineage progression (Knutson et al., 1997).

We considered whether OPC proliferation rate might correlate with the density of voltage-gated potassium channels (Knutson et al., 1997). The cell cycle time for OPCs in the CC of the P21 mouse brain is $\sim 3 \mathrm{~d}$, which is significantly shorter than the cellcycle time for OPCs in the Ctx $(\sim 18 \mathrm{~d}$; Young, Psachoulia, and Richardson, unpublished observations) or aPC ( $\sim 13$ d; Fig. 6). Perhaps coincidentally, in P33 mice, the peak outward current was twofold larger in the CC compared with the other regions (Fig. $5 n$ ), consistent with a potential role for $I_{\mathrm{K}}$ in contributing to the differential proliferation rate in white versus gray matter areas at late developmental times.

\section{OPCs generate OLs but not neurons in the postnatal mouse forebrain}

We and others have reported previously that OPCs generate new neurons in the postnatal mouse brain (Rivers et al., 2008; Guo et al., 2010). We observed very small numbers of YFP ${ }^{+}$, $\mathrm{NeuN}^{+}$neurons throughout the forebrain of Pdgfr $\alpha-\mathrm{CreER}^{T 2}$ : $R 26 R-Y F P$ mice at short times after tamoxifen, but, in general, these neurons did not accumulate with time after tamoxifen, as one would predict if they were produced continually from $\mathrm{YFP}^{+}$precursors and survived long term. Similar observations were made using an independently generated $P d g f r \alpha-$ CreER ${ }^{T 2}$ line (Kang et al., 2010) and an Ng2-CreER line (Zhu et al., 2011), prompting the suggestion that the rare labeled neurons were the result of sporadic activation of the CreER transgenes in a subset of neurons (Kang et al., 2010; Zhu et al., 2011). However, we also observed YFP-labeled neurons in the aPC (but not the posterior piriform cortex; Young and Richardson, unpublished observations) that apparently survived and accumulated for months after tamoxifen treatment (Rivers et al., 2008). We observed a similar accumulation of $\mathrm{mGFP}^{+}$neurons with time in the aPC of Pdgfr $\alpha-C r e E R^{T 2}:$ Tau-mGFP transgenic mice (Fig. 8). It is difficult to understand how this could come about unless these particular neurons are produced continuously in the postnatal aPC from a pool of precursors that become YFP labeled at the time of tamoxifen treatment. In the previous studies, the YFP-labeled neurons were consistently BrdU negative, even after extended BrdU exposure, as were $\sim 50 \%$ of OPCs, leading us to speculate that a subpopulation of mitotically quiescent OPCs might differentiate directly into new aPC neurons without an intervening cell division. Now, using an alternative thymidine analog (EdU), we find that all OPCs in the forebrain are mitotically active (Fig. 6) and so cannot be the source of new neurons in the aPC, which are consistently EdU negative (Fig. 7). Therefore, we now agree with Kang et al. (2010) who found that all OPCs, but no neurons, incorporated BrdU after a long labeling period. Nevertheless, the fact that $\mathrm{YFP}^{+}$neurons accumulate in the aPC after tamoxifen treatment of our Pdgfr $\alpha-C r e E R^{T 2}$ : $R 26 R-Y F P$ mice still requires explanation, as does the apparent discrepancy between our line of $P d g f r \alpha-C r e E R$ mice and the line made by Kang et al. (2010) in which $\mathrm{YFP}^{+}$neurons did not accumulate in the aPC. It is conceivable that our line, but not theirs, marks an unidentified population of $P d g f r \alpha^{+}$neurogenic precursor/stem cells that either resides in the CNS or arrives there via the blood. Additional experiments, e.g., with $P d g f r \alpha-C r e E R$ knock-in mice, will be required to resolve this.

In summary, our data show that OPCs throughout the postnatal brain are electrically excitable, proliferative, and are the precursors of new OLs but do not make neurons at any time that we examined (after P25).

\section{References}

Arisi GM, Foresti ML, Mukherjee S, Shapiro LA (2012) The role of olfactory stimulus in adult mammalian neurogenesis. Behav Brain Res 227:356-362.

Bakiri Y, Attwell D, Káradóttir R (2009) Electrical signalling properties of oligodendrocyte precursor cells. Neuron Glia Biol 5:3-11.

Barres BA, Raff MC (1993) Proliferation of oligodendrocyte precursor cells depends on electrical activity in axons. Nature 361:258-260.

Belachew S, Chittajallu R, Aguirre AA, Yuan X, Kirby M, Anderson S, Gallo V (2003) Postnatal NG2 proteoglycan-expressing progenitor cells are intrinsically multipotent and generate functional neurons. J Cell Biol 161:169-186.

Bergles DE, Roberts JD, Somogyi P, Jahr CE (2000) Glutamatergic synapses on oligodendrocyte precursor cells in the hippocampus. Nature 405:187-191.

Bernier PJ, Bedard A, Vinet J, Levesque M, Parent A (2002) Newly generated neurons in the amygdala and adjoining cortex of adult primates. Proc Natl Acad Sci U S A 99:11464-11469.

Bullmann T, Härtig W, Holzer M, Arendt T (2010) Expression of the embryonal isoform $(0 \mathrm{~N} / 3 \mathrm{R})$ of the microtubule-associated protein tau in the adult rat central nervous system. J Comp Neurol 518:2538-2553.

Chittajallu R, Aguirre A, Gallo V (2004) NG2-positive cells in the mouse 
white and grey matter display distinct physiological properties. J Physiol 561:109-122.

Chittajallu R, Aguirre AA, Gallo V (2005) Downregulation of plateletderived growth factor- $\alpha$ receptor-mediated tyrosine kinase activity as a cellular mechanism for $\mathrm{K}^{+}$-channel regulation during oligodendrocyte development in situ. J Neurosci 25:8601-8610.

Collarini EJ, Kuhn R, Marshall CJ, Monuki ES, Lemke G, Richardson WD (1992) Down-regulation of the POU transcription factor SCIP is an early event in oligodendrocyte differentiation in vitro. Development 116:193-200.

Dayer AG, Cleaver KM, Abouantoun T, Cameron HA (2005) New GABAergic interneurons in the adult neocortex and striatum are generated from different precursors. J Cell Biol 168:415-427.

De Biase LM, Nishiyama A, Bergles DE (2010) Excitability and synaptic communication within the oligodendrocyte lineage. J Neurosci 30:3600-3611.

Demas J, Eglen SJ, Wong RO (2003) Developmental loss of synchronous spontaneous activity in the mouse retina is independent of visual experience. J Neurosci 23:2851-2860.

Demerens C, Stankoff B, Logak M, Anglade P, Allinquant B, Couraud F, Zalc B, Lubetzki C (1996) Induction of myelination in the central nervous system by electrical activity. Proc Natl Acad Sci U S A 93:9887-9892.

Dimou L, Simon C, Kirchhoff F, Takebayashi H, Götz M (2008) Progeny of Olig2-expressing progenitors in the gray and white matter of the adult mouse cerebral cortex. J Neurosci 28:10434-10442.

Ehninger D, Wang LP, Klempin F, Römer B, Kettenmann H, Kempermann G (2011) Enriched environment and physical activity reduce microglia and influence the fate of NG2 cells in the amygdala of adult mice. Cell Tissue Res 345:69-86.

Ge WP, Zhou W, Luo Q, Jan LY, Jan YN (2009) Dividing glial cells maintain differentiated properties including complex morphology and functional synapses. Proc Natl Acad Sci U S A 106:328-333.

Gensert JM, Goldman JE (2001) Heterogeneity of cycling glial progenitors in the adult mammalian cortex and white matter. J Neurobiol 48:75-86.

Goretzki L, Burg MA, Grako KA, Stallcup WB (1999) High-affinity binding of basic fibroblast growth factor and platelet-derived growth factor-AA to the core protein of the NG2 proteoglycan. J Biol Chem 274:16831-16837.

Gudz TI, Komuro H, Macklin WB (2006) Glutamate stimulates oligodendrocyte progenitor migration mediated via an $\alpha \mathrm{v}$ integrin/myelin proteolipid protein complex. J Neurosci 26:2458-2466.

Guo F, Maeda Y, Ma J, Xu J, Horiuchi M, Miers L, Vaccarino F, Pleasure D (2010) Pyramidal neurons are generated from oligodendroglial progenitor cells in adult piriform cortex. J Neurosci 30:12036-12049.

Hamilton TG, Klinghoffer RA, Corrin PD, Soriano P (2003) Evolutionary divergence of platelet-derived growth factor alpha receptor signaling mechanisms. Mol Cell Biol 23:4013-4025.

Hayashi T, Seki T, Sato K, Iwai M, Zhang WR, Manabe Y, Abe K (2001) Expression of polysialylated neural cell adhesion molecule in rat brain after transient middle cerebral artery occlusion. Brain Res 907:130-133.

Hippenmeyer S, Vrieseling E, Sigrist M, Portmann T, Laengle C, Ladle DR, Arber S (2005) A developmental switch in the response of DRG neurons to ETS transcription factor signaling. PLoS Biol 35:e159.

Kang SH, Fukaya M, Yang JK, Rothstein JD, Bergles DE (2010) NG2+ CNS glial progenitors remain committed to the oligodendrocyte lineage in postnatal life and following neurodegeneration. Neuron 68:668-681.

Káradóttir R, Hamilton NB, Bakiri Y, Attwell D (2008) Spiking and nonspiking classes of oligodendrocyte precursor glia in CNS white matter. Nat Neurosci 11:450-456.

Keirstead HS, Levine JM, Blakemore WF (1998) Response of the oligodendrocyte progenitor cell population (defined by NG2 labelling) to demyelination of the adult spinal cord. Glia 22:161-170.

Knutson P, Ghiani CA, Zhou JM, Gallo V, McBain CJ (1997) K ${ }^{+}$channel expression and cell proliferation are regulated by intracellular sodium and membrane depolarization in oligodendrocyte progenitor cells. J Neurosci 17:2669-2682.

Kukley M, Capetillo-Zarate E, Dietrich D (2007) Vesicular glutamate release from axons in white matter. Nat Neurosci 10:311-320.

Kukley M, Kiladze M, Tognatta R, Hans M, Swandulla D, Schramm J, Dietrich D (2008) Glial cells are born with synapses. FASEB J 22:2957-2969.

Kukley M, Nishiyama A, Dietrich D (2010) The fate of synaptic input to
NG2 glial cells: neurons specifically downregulate transmitter release onto differentiating oligodendroglial cells. J Neurosci 30:8320-8331.

Li Q, Brus-Ramer M, Martin JH, McDonald JW (2010) Electrical stimulation of the medullary pyramid promotes proliferation and differentiation of oligodendrocyte progenitor cells in the corticospinal tract of the adult rat. Neurosci Lett 479:128-133.

Lin G, Mela A, Guilfoyle EM, Goldman JE (2009) Neonatal and adult $\mathrm{O} 4(+)$ oligodendrocyte lineage cells display different growth factor responses and different gene expression patterns. J Neurosci Res $87: 3390-3402$.

Lin SC, Bergles DE (2004) Synaptic signaling between GABAergic interneurons and oligodendrocyte precursor cells in the hippocampus. Nat Neurosci 7:24-32.

Lytle JM, Chittajallu R, Wrathall JR, Gallo V (2009) NG2 cell response in the CNP-EGFP mouse after contusive spinal cord injury. Glia 57:270-285.

Mallon BS, Shick HE, Kidd GJ, Macklin WB (2002) Proteolipid promoter activity distinguishes two populations of NG2-positive cells throughout neonatal cortical development. J Neurosci 22:876-885.

Mao BQ, Hamzei-Sichani F, Aronov D, Froemke RC, Yuste R (2001) Dynamics of spontaneous activity in neocortical slices. Neuron 32:883-898.

Meister M, Wong RO, Baylor DA, Shatz CJ (1991) Synchronous bursts of action potentials in ganglion cells of the developing mammalian retina. Science 252:939-943.

Mohns EJ, Blumberg MS (2008) Synchronous bursts of neuronal activity in the developing hippocampus: modulation by active sleep and association with emerging gamma and theta rhythms. J Neurosci 28:10134-10144.

Murtie JC, Macklin WB, Corfas G (2007) Morphometric analysis of oligodendrocytes in the adult mouse frontal cortex. J Neurosci Res 85:2080-2086.

Nacher J, Alonso-Llosa G, Rosell D, McEwen B (2002) PSA-NCAM expression in the piriform cortex of the adult rat. Modulation by NMDA receptor antagonist administration. Brain Res 927:111-121.

Pekcec A, Löscher W, Potschka H (2006) Neurogenesis in the adult rat piriform cortex. Neuroreport 17:571-574.

Power J, Mayer-Pröschel M, Smith J, Noble M (2002) Oligodendrocyte precursor cells from different brain regions express divergent properties consistent with the differing time courses of myelination in these regions. Dev Biol 245:362-375.

Pringle N, Collarini EJ, Mosley MJ, Heldin CH, Westermark B, Richardson WD (1989) PDGF A chain homodimers drive proliferation of bipotential $(\mathrm{O}-2 \mathrm{~A})$ glial progenitor cells in the developing rat optic nerve. EMBO J 8:1049-1056.

Psachoulia K, Jamen F, Young KM, Richardson WD (2009) Cell cycle dynamics of NG2 cells in the postnatal and ageing brain. Neuron Glia Biol 5:57-67.

Richardson WD, Young KM, Tripathi RB, McKenzie I (2011) NG2-glia as multipotent neural stem cells: fact or fantasy? Neuron 70:661-673.

Rivers LE, Young KM, Rizzi M, Jamen F, Psachoulia K, Wade A, Kessaris N, Richardson WD (2008) PDGFRA/NG2 glia generate myelinating oligodendrocytes and piriform projection neurons in adult mice. Nat Neurosci 11:1392-1401.

Seki T, Arai Y (1999) Temporal and spacial relationships between PSANCAM-expressing, newly generated granule cells, and radial glia-like cells in the adult dentate gyrus. J Comp Neurol 410:503-513.

Shapiro LA, Ng KL, Kinyamu R, Whitaker-Azmitia P, Geisert EE, BlurtonJones M, Zhou QY, Ribak CE (2007) Origin, migration and fate of newly generated neurons in the adult rodent piriform cortex. Brain Struct Funct 212:133-148.

Simon C, Götz M, Dimou L (2011) Progenitors in the adult cerebral cortex: cell cycle properties and regulation by physiological stimuli and injury. Glia 59:869-881.

Srinivas S, Watanabe T, Lin CS, William CM, Tanabe Y, Jessell TM, Costantini F (2001) Cre reporter strains produced by targeted insertion of EYFP and ECFP into the ROSA26 locus. BMC Dev Biol 1:4.

Sugiarto S, Persson AI, Munoz EG, Waldhuber M, Lamagna C, Andor N, Hanecker P, Ayers-Ringler J, Phillips J, Siu J, Lim DA, Vandenberg S, Stallcup W, Berger MS, Bergers G, Weiss WA, Petritsch C (2011) Asymmetry-defective oligodendrocyte progenitors are glioma precursors. Cancer Cell 20:328-340.

Tamura Y, Kataoka Y, Cui Y, Takamori Y, Watanabe Y, Yamada H (2007) Multi-directional differentiation of doublecortin- and NG2-immunoposi- 
tive progenitor cells in the adult rat neocortex in vivo. Eur J Neurosci 25:3489-3498.

Tong XP, Li XY, Zhou B, Shen W, Zhang ZJ, Xu TL, Duan S (2009) $\mathrm{Ca}^{2+}$ signaling evoked by activation of $\mathrm{Na}^{+}$channels and $\mathrm{Na}^{+} / \mathrm{Ca}^{2+}$ exchangers is required for GABA-induced NG2 cell migration. J Cell Biol 186:113-128.

Tripathi RB, Clarke LE, Burzomato V, Kessaris N, Anderson PN, Attwell D, Richardson WD (2011) Dorsally and ventrally derived oligodendrocytes have similar electrical properties but myelinate preferred tracts. J Neurosci 31:6809-6819.

Vinet J, Lemieux P, Tamburri A, Tiesinga P, Scafidi J, Gallo V, Sík A (2010) Subclasses of oligodendrocytes populate the mouse hippocampus. Eur J Neurosci 31:425-438.

Wake H, Lee PR, Fields RD (2011) Control of local protein synthesis and initial events in myelination by action potentials. Science 333:1647-1651.

Watt AJ, Cuntz H, Mori M, Nusser Z, Sjöström PJ, Häusser M (2009) Traveling waves in developing cerebellar cortex mediated by asymmetrical Purkinje cell connectivity. Nat Neurosci 12:463-473.
Young KM, Merson TD, Sotthibundhu A, Coulson EJ, Bartlett PF (2007) p75 neurotrophin receptor expression defines a population of BDNFresponsive neurogenic precursor cells. J Neurosci 27:5146-5155.

Yuan X, Eisen AM, McBain CJ, Gallo V (1998) A role for glutamate and its receptors in the regulation of oligodendrocyte development in cerebellar tissue slices. Development 125:2901-2914.

Zhu G, Mehler MF, Zhao J, Yu Yung S, Kessler JA (1999) Sonic hedgehog and BMP2 exert opposing actions on proliferation and differentiation of embryonic neural progenitor cells. Dev Biol 215:118-129.

Zhu X, Bergles DE, Nishiyama A (2008) NG2 cells generate both oligodendrocytes and gray matter astrocytes. Development 135:145-157.

Zhu X, Hill RA, Dietrich D, Komitova M, Suzuki R, Nishiyama A (2011) Age-dependent fate and lineage restriction of single NG2 cells. Development 138:745-753.

Ziskin JL, Nishiyama A, Rubio M, Fukaya M, Bergles DE (2007) Vesicular release of glutamate from unmyelinated axons in white matter. Nat Neurosci 10:321-330. 